\title{
Biochemical and Functional Characterization of Kidney Bean Protein Alcalase-Hydrolysates and Their Preservative Action on Stored Chicken Meat
}

\author{
Ahmed M. Saad ${ }^{1}$ (D), Mahmoud Z. Sitohy ${ }^{1, *}$, Alshaymaa I. Ahmed ${ }^{2}$, Nourhan A. Rabie ${ }^{3}$, Shimaa A. Amin ${ }^{4}$, \\ Salama M. Aboelenin ${ }^{5}$, Mohamed M. Soliman ${ }^{6}(\mathbb{D})$ and Mohamed T. El-Saadony ${ }^{7}$ (D) \\ 1 Biochemistry Department, Faculty of Agriculture, Zagazig University, Zagazig 44511, Egypt; \\ AMMousttafa@agri.zu.edu.eg \\ 2 Department of Agricultural Microbiology, Faculty of Agriculture, Beni-Suef University, Beni-Suef 62511, Egypt; \\ Alshaymaaibrahim@gmail.com \\ 3 Department of Food Science, Faculty of Agriculture, Zagazig University, Zagazig 44511, Egypt; \\ Rabienourhan882@gmail.com \\ 4 Department of Agricultural Microbiology, Faculty of Agriculture, Ain-Shams University, Cairo 11566, Egypt; \\ shimaa_amin@agr.asu.edu.eg \\ 5 Biology Department, Turabah University College, Taif University, P.O. Box 1109, Taif 21944, Saudi Arabia; \\ s.aboelenin@tu.edu.sa \\ check for \\ updates \\ Citation: Saad, A.M.; Sitohy, M.Z.; \\ Ahmed, A.I.; Rabie, N.A.; Amin, S.A.; \\ Aboelenin, S.M.; Soliman, M.M.; \\ 6 Clinical Laboratory Sciences Department, Turabah University College, Taif University, P.O. Box 11099, \\ Taif 21944, Saudi Arabia; mmsoliman@tu.edu.sa \\ 7 Department of Agricultural Microbiology, Faculty of Agriculture, Zagazig University, Zagazig 44511, Egypt; \\ m.talaatelsadony@gmail.com \\ * Correspondence: mzsitohy@zu.edu.eg
} El-Saadony, M.T. Biochemical and Functional Characterization of Kidney Bean Protein

Alcalase-Hydrolysates and Their Preservative Action on Stored Chicken Meat. Molecules 2021, 26, 4690. https://doi.org/10.3390/ molecules 26154690

Academic Editor: Monica Rosa Loizzo

Received: 14 June 2021

Accepted: 27 July 2021

Published: 3 August 2021

Publisher's Note: MDPI stays neutral with regard to jurisdictional claims in published maps and institutional affiliations.

Copyright: (c) 2021 by the authors. Licensee MDPI, Basel, Switzerland. This article is an open access article distributed under the terms and conditions of the Creative Commons Attribution (CC BY) license (https:// creativecommons.org/licenses/by/ $4.0 /)$.

\begin{abstract}
A new preservation approach is presented in this article to prolong the lifetime of raw chicken meat and enhance its quality at $4{ }^{\circ} \mathrm{C}$ via coating with highly soluble kidney bean protein hydrolysate. The hydrolysates of the black, red, and white kidney protein $(\mathrm{BKH}, \mathrm{RKH}$, and $\mathrm{WKH})$ were obtained after 30 min enzymatic hydrolysis with Alcalase (E/S ratio of 1:100, hydrolysis degree 25-29\%). The different phaseolin subunits (8S) appeared in SDS-PAGE in 35-45 kD molecular weight range while vicilin appeared in the molecular weight range of $55-75 \mathrm{kD}$. The kidney bean protein hydrolysates have considerable antioxidant activity as evidenced by the DPPH-scavenging activity and $\beta$-carotine-linolenic assay, as well as antimicrobial activity evaluated by disc diffusion assay. BKH followed by RKH $(800 \mu \mathrm{g} / \mathrm{mL})$ significantly $(p \leq 0.05)$ scavenged $95,91 \%$ of DPPH and inhibited $82-88 \%$ of linoleic oxidation. The three studied hydrolysates significantly inhibited the growth of bacteria, yeast, and fungi, where BKH was the most performing. Kidney bean protein hydrolysates could shield the chicken meat because of their amphoteric nature and many functional properties (water and oil-absorbing capacity and foaming stability). The quality of chicken meat was assessed by tracing the fluctuations in the chemical parameters $(\mathrm{pH}$, met-myoglobin, lipid oxidation, and TVBN), bacterial load (total bacterial count, and psychrophilic count), color parameters and sensorial traits during cold preservation $\left(4^{\circ} \mathrm{C}\right)$. The hydrolysates $(800 \mu \mathrm{g} / \mathrm{g})$ significantly $p \leq 0.05$ reduced the increment in meat $\mathrm{pH}$ and TVBN values, inhibited $59-70 \%$ of lipid oxidation as compared to control during 30 days of cold storage via eliminating $50 \%$ of bacterial load and maintained secured storage for 30 days. RKH and WKH significantly $(p \leq 0.05)$ enhanced $L^{*}, a^{*}$ values, thus augmented the meat whiteness and redness, while, $\mathrm{BKH}$ increased $b^{*}$ values, declining all color parameters during meat storage. RKH and WKH $(800 \mu \mathrm{g} / \mathrm{g})(p \leq 0.05)$ maintained $50-71 \%$ and $69-75 \%$ of meat color and odor, respectively, increased the meat juiciness after 30 days of cold storage. BKH, RKH and WKH can be safely incorporated into novel foods.
\end{abstract}

Keywords: legume protein isolation; enzymatic hydrolysis; phaseolin; antioxidant; antimicrobial; chicken meat cold storage 


\section{Introduction}

Poultry meat is one of the most popular foods worldwide. However, increasing consumer awareness about meat origin, animal welfare, and meat safety challenges the production of high-quality meat. Microbial contamination, lipid, and protein oxidation are the main problems affecting chicken meat quality. Consumer rejection and economic losses might result from muscle components oxidation and discoloration, as well as the contamination of chicken meat with foodborne pathogens during processing and marketing or the inappropriate meat cooking, cooling or storage causing illness or sometimes death. These factors cost billions of dollars in medical and social care [1]. Centers for Disease Control and Prevention (CDC) estimates that foodborne pathogens lead to 48 million sick people, 128,000 hospitalized people, and 3000 deaths every year [2]. Currently, consumers need high-quality food with extended shelf life and reasonable prices. Therefore, food producers employ researchers to find food additives that meet consumer desires. Chemical additives, i.e., nitrate, butylated hydroxyanisole (BHA), and butylated hydroxytoluene (BHT) are highly efficient in preserving foods and prolonging the storage period by reducing chemical and biological changes $[3,4]$. However, these chemicals are expensive and may cause various damages to health when intensively used. Therefore, consumers prefer natural preservatives. Researchers sought to preserve various foods with biologically active natural additives [5-9]. The new trend in food preservation uses bioactive peptides as natural additives to preserve milk [10-15], meat products [16-18]. These proteins can generate bioactive peptides under enzymatic hydrolysis [19-21]. Fermentation and digestion in the gastrointestinal (GI) can also generate bioactive peptides [22]. Bioactive peptides consist of about 2-20 amino acids and have a relatively low molecular weight compared to proteins [23], facilitating their absorption into the small intestine and promoting their biological effects [24]. The behavior of these bioactive peptides depends on their weight and length, their structure and sequence of amino acids, hydrophobic/hydrophilic properties, spatial structure, and charge character of the constituting amino acid $[25,26]$. Biologically active peptides, especially isolated from plants are characterized by their antioxidant and antimicrobial activities. Therefore, they have a role in improving the food quality and technological properties. [27].

White, red, and dark kidney beans (Phaseolus vulgarus L.) members of Fabaceae, have a considerable content of protein $(25-44 \%)$, and other nutrients [28,29]. Various studies investigated that common beans contributed in many diseases treatments, i.e., cancer and diabetes [30]. Phaseolin " $8 \mathrm{~S}$ " is the main storage protein in kidney bean [31]. Phaseolins have medium molecular weight in the range $43-55 \mathrm{kD}$ and are encompassing potentially bioactive oligopeptides of 2-20 amino acids' sizes [32]. These bioactive peptides (BPs) inherent in the legume seeds can be liberated and produced under the action of different proteases such as Alcalase, Pepsin, Trypsin, and Papain [21]. These BPs were reported to exhibit antibacterial activity against various spoilage bacteria and exert antioxidant activity against lipid oxidation $[9,15,18]$. Therefore, they can be incorporated into different functional foods [33]. Alcalase is endopeptidase enzyme isolated from Bacillus licheniformis, it can hydrolyze several proteins to small peptides. The hydrolysis activity of alcalase was more activity than trypsin and papain [34]. Enzymatic hydrolysis reduces the polypeptide size, and increase the bioavailability of amino acid in the human and animal diet [35]. Bumrungsart and Duangmal [36] explored the influence of Flavourzyme ${ }^{\circledR}(1-7 \%)$ on a two $\mathrm{h}$ hydrolysis of gram bean protein isolate on the structure and antioxidant activity of the resulting peptides [37]. Saad, et al. [21] investigated the influence of incorporating various protein hydrolysates into meat products and juices as potential natural preservatives $[38,39]$. In this study, three protein hydrolysates (WKH, RKH, and BKH) were obtained from white, red, and black kidney bean protein by 30-min Alcalase hydrolysis. The hydrolysates were physicochemically characterized. The preservative action of hydrolysates were followed on stored chicken meat at cold conditions for 30 days. 


\section{Materials and Methods}

Black, red, and white kidney bean seeds (Phaseolus vulgaris L) were acquired from a local market in Cairo City, Egypt, and raw chicken meat samples were obtained from a private farm at Zagazig City, Egypt. Alcalase enzyme and DPPH were from (SigmaAldrich, Inc., St. Louis, MO 68178, USA), and Muller Hinton agar (Oxoid, Basingstoke, UK). Electrophoresis reagents were from Bio-Rad laboratories (Sigma-Aldrich, Inc., St. Louis, MO 68178, USA). All chemicals were of analytical grade. The microorganisms used in this study to fully assess the antimicrobial activity included; Bacillus cereus, Listeria monocytogenes, Staphylococcus pyogenes, Escherichia coli, Campylobacter jejuni, Salmonella typhi, Aspergillus niger, Aspergillus fumigatus, Aspergillus flavus, Penicillium chrysogenum, Fusarium exquisite, Fusarium avenaceum, Candida gelbeta, Candida tropicalis, Candida albicans, Rhodotorula rubra, Rhodotorula minuta, and Rhodotorula mucilginosa. These isolates were obtained from Agricultural Microbiology Department, Faculty of Agriculture, Zagazig University, Zagazig, Egypt.

\subsection{Protein and Peptides Isolation}

\subsubsection{Black, Red and White Kidney Bean Protein Isolates (BKI, RKI, and WKI)}

The black, red, and white bean seeds were cleaned and ground by Moulinex blender Type 716 (France) to pass through a $1 \mathrm{~mm} 2$ sieve. The powder was defatted by hexane in a Soxhlet apparatus. WKI, RKI, and BKI were isolated from defatted powder according to the method of [40], with some modifications. Defatted flours were homogenized in distilled water $(5 \% w / v)$, and $\mathrm{pH}$ was adjusted to 8 with $\mathrm{NaOH}(2 \mathrm{~N})$. The suspension was stirred for two hours at room temperature before centrifugation at $4000 \times g, 30 \mathrm{~min}$. The $\mathrm{pH}$ of supernatants was adjusted to 4.5 with $\mathrm{HCl}(2 \mathrm{~N})$, and the resulting precipitates (proteins) were recovered by centrifugation at $4000 \times g, 30 \mathrm{~min}$, homogenized again in distilled water, and $\mathrm{pH}$ was adjusted to 7.0 with $2 \mathrm{~N} \mathrm{NaOH}$, dialyzed, then lyophilized.

\subsubsection{Black, Red and White Kidney Bean Alcalase Enzymatic Hydrolysates}

The BKI, RKI, and WKI were blended with Alcalase $(1: 100, w / w)$ then dissolved in phosphate buffer $\mathrm{pH} 6$, and incubated at $37^{\circ} \mathrm{C}$ for intervals $(0,30$, and $60 \mathrm{~min})$. The temperature was raised to $90{ }^{\circ} \mathrm{C}$ for $15 \mathrm{~min}$ to inhibit the enzyme. The White, red, black kidney bean hydrolysates $(\mathrm{BKH}, \mathrm{RKH}$, and $\mathrm{WKH})$ were obtained by centrifugation at $(4000 \times g, 30 \mathrm{~min})$, lyophilized and kept at $-20^{\circ} \mathrm{C}$ for further analysis $[15,21]$.

\subsection{Biochemical Characterization of White, Red, Black Kidney Bean Protein and Hydrolysates 2.2.1. Degree of Hydrolysis (DH)}

The DHs of BKI, RKI, and WKI after 30 and 60 min were estimated by the method of Holye and Merrltt [41]. One $\mathrm{mL}$ of protein isolate supernatant was dissolved in trichloroacetic acid (TCA, 10\%) (1:1 v/v), then centrifuged at $\left(10,000 \mathrm{rpm}, 10 \mathrm{~min}, 4{ }^{\circ} \mathrm{C}\right)$ (Sigma 3-30 k, Germany) to collect TCA supernatant. Total nitrogen in TCA supernatant and the protein isolates was measured by the Kjeldahl method [21]:

$$
\text { Degree of hyrolysis }(\%)=\frac{\text { TCA } 10 \%-\text { Soluble nitrogen in the sample }}{\text { Total nitrogen in the sample }} \times 100
$$

\subsubsection{Sodium Dodecyl Sulfate Polyacrylamide Gel Electrophoresis (SDS-PAGE)}

The BKI, RKI, and WKI and alcalase hydrolysates (WKH, RKH, and BKH) were fractionated by discontinuous SDS-PAGE according to Laemmli [42]. An amount of $20 \mu \mathrm{g}$ of peptides was dispersed in $100 \mu \mathrm{L}$ of reducing SDS-loading sample buffer $\mathrm{pH}$ 6.8, heated at $96{ }^{\circ} \mathrm{C}$ for $3 \mathrm{~min}$ then was centrifuged at 14,000 rpm for $10 \mathrm{~min}$ and $5 \mu \mathrm{L}$ aliquot was electrophoresed ( $5 \mu \mathrm{L}$ of protein/lane). In the present procedure, the resolving $(18 \%)$ and stacking gels $(10 \%)$ were prepared. The electrophoresis was run toward the positive pole at $10 \mathrm{~mA}$ on the stacking gel and $20 \mathrm{~mA}$ on the resolving gel. After electrophoretic separation, the gels were carefully removed and the bands was stabilized in $300 \mathrm{~mL}$ of 
$10 \%$ trichloroacetic acid (TCA) for $12 \mathrm{~h}$ at room temperature. The protein bands were developed with Commassie Brilliant Blue R-250 dye and molecular weight of separated proteins bands were identified by ChemiDoc Gel documentation (BioRad, Hercules, CA, USA). A molecular weight marker in the range of 6.5 to $245 \mathrm{kDa}$ was used.

\subsubsection{Chemical Analysis of Hydrolysates}

The proximate analysis (Protein, Carbohydrates, Fat, Ash, and Moisture) of WKH, $\mathrm{RKH}$, and BKH were estimated according to Roy, et al. [43].

\subsubsection{Functional Properties of Hydrolysates} Hydrolysates Solubility

The solubility of protein hydrolysates was measured at $\mathrm{pH}$ range (2-10) according to [44] with slight modifications. An amount of $100 \mathrm{mg}$ of protein hydrolysates was homogenized in $25 \mathrm{~mL}$ of distilled water and $\mathrm{pH}$ was adjusted using $\mathrm{pH}$ meter ( $\mathrm{pH} 211$ HANNA instruments Inc. Woonsocket USA made in Romania). The protein hydrolysates suspensions were stirred for $1 \mathrm{~h}$ at $30^{\circ} \mathrm{C}$, and then centrifuged at $\left(1200 \times g, 20 \mathrm{~min}, 4^{\circ} \mathrm{C}\right)$ to obtain the supernatant then protein content was measured by the Kjeldahl method [45]. The peptides solubility (\%) was measured against $\mathrm{pH}$ following the equation:

$$
\text { Solubility }(\%)=\frac{\text { Protein content in supernatant }}{\text { Protein content in sample }} \times 100
$$

\section{Water Absorption Capacity}

Water absorption capacity was estimated as Wani, et al. [46] with slight modifications; $1 \mathrm{~g}$ of each protein hydrolysate was mixed with $10 \mathrm{~mL}$ of distilled water in weighted test tubes, stirred for $30 \mathrm{~min}$, then centrifuged at $6000 \times \mathrm{g}$ for $30 \mathrm{~min}$, and the supernatant was discarded. The tubes remained at $45^{\circ} \mathrm{C}$ for $25 \mathrm{~min}$ at a $45^{\circ}$ angle until surface water was removed, then weighted again. Water absorption percentage was expressed as $\mathrm{g}$ of absorbed water/g of sample.

\section{Oil Absorption Capacity}

Oil absorption capacity was determined as Wani, et al. [46] with some modifications. $0.5 \mathrm{~g}$ of each hydrolysate was added to $6 \mathrm{~mL}$ of oil in weighted test tubes, stirred for $30 \mathrm{~min}$, then centrifuged at $6000 \times g$ for $30 \mathrm{~min}$, and the supernatant was discarded. After removing the supernatant, the tubes were kept upside-down for $25 \mathrm{~min}$ to remove the excess oil and weighted again. Oil absorption percentage was calculated as $\mathrm{g}$ absorbed oil/g of sample.

\section{Foaming Capacity and Foaming Stability}

Foaming capacity was estimated according to Wani, et al. [47] with slight modifications; $1 \mathrm{~g}$ of each hydrolysate was mixed at high speed with $50 \mathrm{~mL}$ distilled water in a Moulinex mixer Type 716 (France) for $5 \mathrm{~min}$. Then, the solution was poured into a scaled cylinder $(250 \mathrm{~mL})$ and foam volume was read after $30 \mathrm{~s}$. The foam stability was determined by recording the foam volume through time. Foaming activity was calculated using the following equation:

$$
\mathrm{FC}(\%)=\frac{(\mathrm{A} 0-\mathrm{B}) \times 100}{\mathrm{~B}}
$$

where \% foaming capacity (FC), is, and sample volume before stirring (B), and sample volume after stirring (A0).

2.2.5. Chemical Constituents of the Hydrolysates

Total Phenolic Compounds (TPC) in The Hydrolysates

Polyphenols were assessed in BKH, RKH, and WKH suspension and calculated as mg GAE/g following Folin-Ciocalteu method Škerget, et al. [48], the absorbance was examined 
at $750 \mathrm{~nm}$ using a spectrophotometer (JENWAY $6405 \mathrm{UV} /$ visible, UK) and was applied in standard Gallic acid linear (equation: $y=0.004 x+0.1257$ ).

Total Flavonoids in the Hydrolysates

An aliquot $(100 \mu \mathrm{L})$ of each hydrolysate suspension was homogenized in $3 \mathrm{~mL}$ of ethanoic $\mathrm{AlCl}_{3}$ and kept for an hour in the dark as per [49]. The absorbance at $430 \mathrm{~nm}$ was measured and applied in the standard quercetin linear (equation: $y=0.0025 x-0.0057$ ), to obtain total flavonoids content as $\mu \mathrm{g} \mathrm{QE} / \mathrm{mL}$.

Total Anthocyanin Content (TAC) in BKH, RKH, and WKH Peptides

Total anthocyanin content in $\mathrm{BKH}, \mathrm{RKH}$, and WKH was evaluated at different $\mathrm{pH}$ (1 and 4.5) by spectrophotometer [50]. The change in absorbance of the supernatant was measured at 520 and $700 \mathrm{~nm}$. The total monomeric anthocyanin was presented as cyanidin-3-Glu equivalent ( $\mathrm{mg} / \mathrm{g}$ ) in the following Equation (4):

$$
\begin{aligned}
& \text { Amount of anthocyanin }(\mathrm{mg} / \mathrm{g})=\frac{\mathrm{A} \times 449.2 \times \mathrm{DF} \times 10^{3}}{26,900} \\
& \mathrm{~A}=(\mathrm{A} 520-\mathrm{A} 700) \mathrm{pH} 1.0-(\mathrm{A} 520-\mathrm{A} 700) \mathrm{pH} 4.5
\end{aligned}
$$

\subsubsection{Biological Activity of Hydrolysates}

Antioxidant Activity

\section{DPPH Assay}

The radical scavenging activity of $\mathrm{BKH}, \mathrm{RKH}$, and WKH levels (50, 100, 200, 400, and $800 \mu \mathrm{g} / \mathrm{mL}$ ) was deduced from the ability to convert the purple color of $\mathrm{DPPH}^{*}$ to yellow as compared to TBHQ as synthetic antioxidant according to Hatano, et al. [51] with some modifications. An aliquot $(100 \mu \mathrm{L})$ of each hydrolysate level was mixed with $1 \mathrm{~mL}$ ethanolic DPPH and incubated for $30 \mathrm{~min}$ in the dark. The absorbance (Abs) was estimated at $517 \mathrm{~nm}$ against the control. DPPH ${ }^{*}$ antiradical activity (\%) was calculated in the following equation:

$$
\text { Radical scavenging activity }(\%)=\frac{(\text { Abs.control }- \text { Abs.sample })}{(\text { Abs.control })} \times 100
$$

$\beta$-Carotene/Linoleic Acid Bleaching

The ability of BKH, RKH, and $\mathrm{WKH}(50,100,200,400$, and $800 \mu \mathrm{g} / \mathrm{mL})$ to prevent discoloration of $\beta$-carotene was determined following Dastmalchi, et al. [52]. In brief, $0.2 \mathrm{mg}$ of $\beta$-carotene was homogenized in $1 \mathrm{~mL}$ of chloroform, $20 \mathrm{mg}$ of linoleic acid, and $200 \mathrm{mg}$ of tween 20 were added in a round-bottom flask. The chloroform was evaporated, and $50 \mathrm{~mL}$ of distilled water was added, and the mixture was vigorously stirred. An aliquot $(0.5 \mathrm{~mL})$ of each hydrolysate suspension was mixed with $3 \mathrm{~mL}$ of the $\beta$-Carotene/linoleic emulsion, and the absorbance ( $\mathrm{Abs} 0$ ) was measured at $470 \mathrm{~nm}$ was recorded. The other samples were incubated at $50{ }^{\circ} \mathrm{C}$ for $120 \mathrm{~min}$, and the absorbance was similarly recorded at $470 \mathrm{~nm}$ (Abs120). A control without hydrolysate was similarly assayed. Antioxidant activity was calculated as follows:

$$
\text { Antioxidant activity }(\%)=1-\frac{\text { Abs0 sample }- \text { Abs120 sample }}{\text { Abs0 control }- \text { Abs120 control }} \times 100
$$

where $\mathrm{Abs}_{0}$ sample is the absorbance of sample at 0-time, $\mathrm{Abs}_{120}$ sample is the absorbance after $120 \mathrm{~min}, \mathrm{Abs}_{0}$ control is the absorbance of control at 0 -time, and $\mathrm{Abs}_{120}$ control is the absorbance of control after $120 \mathrm{~min}$.

Antimicrobial Activity

Antibacterial

Antibacterial activity was estimated by disc diffusion assay according to El-Saadony, et al. [53]. Muller Hinton agar (MHA) plates were inoculated with activated 
bacterial isolates. Discs $(6 \mathrm{~mm})$ were saturated with protein hydrolysates concentrations $(50,100,200,400$, and $800 \mu \mathrm{g} / \mathrm{mL})$ then placed on the surface of MHA plates and incubated for $24 \mathrm{~h}$ at $37^{\circ} \mathrm{C}$. The discs were saturated with sterilized distilled water used a control. The ruler was used to measure the zones of inhibition surrounding the discs (mm). The least concentration-inducing growth inhibition of bacteriaa was considered the minimum inhibitory concentration (MIC). The MIC was estimated by adding $50 \mu \mathrm{L}$ of each level of tested hydrolysates $(50,100,200,400$, and $800 \mu \mathrm{g} / \mathrm{mL}$ ) to $9 \mathrm{~mL}$ MHB inoculated with $100 \mu \mathrm{L}$ pathogenic bacteria. The tubes were incubated for $24 \mathrm{~h}$ at $37^{\circ} \mathrm{C}$, and the turbidity was recorded at $600 \mathrm{~nm}$ [54]. The least concentration totally kill the tested bacteria was, the minimum bactericidal concentration (MBC) was estimated by spreading $100 \mu \mathrm{L}$ of each hydrolysate MIC on MHA plates' surface then incubated at $37^{\circ} \mathrm{C}$ for $24 \mathrm{~h}$ and the bacterial growth was observed.

Antifungal

The tested Candida and fungi species were cultured on Sabouraud dextrose agar (SDA) plates, and were incubated at $37^{\circ}$ and $30^{\circ} \mathrm{C}$ for 2 , and 5 days, respectively. The antifungal activities of BKH, RKH, and WKH $(50,100,200,400$, and $800 \mu \mathrm{g} / \mathrm{mL})$ were evaluated using the disc assay [15]. The SD broth tubes inoculated with Candida spp., or fungal spore suspension were incubated at $37^{\circ} \mathrm{C}$ and $30^{\circ} \mathrm{C}$ for 2 and 5 day, respectively to get inoculum $\left(10^{5} \mathrm{CFU} \mathrm{m} \mathrm{m}^{-1}\right)$ concentration. An aliquot $(100 \mu \mathrm{L})$ of Candida and fungal inoculum was spread over SDA plates. The saturated paper discs $(6 \mathrm{~mm})$ with $\mathrm{BKH}, \mathrm{RKH}$, and $\mathrm{WKH}$ $(50,100,200,400$, and $800 \mu \mathrm{g} / \mathrm{mL})$ were placed on the sides of cultivated SDA plates. The plates were incubated at $37^{\circ} \mathrm{C}$ for 2 days (Candida) and $30^{\circ} \mathrm{C}$ for 5 days (Fungi). The resultant zones around the discs were measured by ruler indicating antifungal activity of tested hydrolysates. The minimum inhibitory concentration (MIC) of the hydrolysate was evaluated by the micro-dilution broth method [55]. The SDB tubes contained hydrolysates concentrations and Candida or fungal inoculum were incubated at $37^{\circ} \mathrm{C}$ for 2 day (Candida) or $30^{\circ} \mathrm{C}$ for 5 days (fungi). The obtained turbidity was read at $600 \mathrm{~nm}$ using a spectrophotometer (Shimadzu Corporation, Analytical Instruments Division, Kyoto, Japan). The lowest hydrolysate concentration inhibiting the fungal growth, was recorded as the MIC and the lowest concentration totally removing the fungal growth was considered the minimum fungicidal concentration (MFC) [55]. The MIC levels of BKH, RKH, and WKH was sub-culturing the onto SDA plates to calculate minimum fungicidal concentration (MFC). The plates were incubated at $30^{\circ} \mathrm{C}$ for $3-5$ days (fungi) or $37^{\circ} \mathrm{C}$ for 2 day (Candida).

\subsection{Preservation of Raw Chicken Meat}

Chicken muscles $(500 \mathrm{~g})$ were cut with a sterile knife to $4 \mathrm{~cm}$-cubes. The meat samples were transferred to sterilized polyethylene packets, then divided into 4 groups (control; T1, chicken meat cubes soaked in different concentrations of WKH $(200,400$, and 800) for $24 \mathrm{~h}$; T2, chicken meat cubes soaked in different concentrations of RKH, and T3, chicken meat cubes soaked in different concentrations of BKH). All samples were air-dried under sterilization conditions. The treated samples were stored in plastic bags and stored at $4{ }^{\circ} \mathrm{C}$ for 4 weeks for different analysis.

\subsubsection{Physicochemical Analysis of Meat Sample pH Estimation}

Five grams of meat samples were minced in a sterilized mincer and homogenized in $45 \mathrm{~mL}$ distilled water for $30 \mathrm{~min}$, and filtrated. The $\mathrm{pH}$ of chicken meat filtrate $\mathrm{pH}$ was estimated as Özyurt, et al. [56] using a pH-meter (pH 211 HANNA instruments Inc., Woonsocket, RI, USA).

\section{Metmyoglobin (MetMb) Analysis}

The MetMb contents in raw chicken meat samples were determined as per Badr [57]. Chicken meat samples $(5 \mathrm{~g})$ were homogenized in $25 \mathrm{~mL}$ of $40 \mathrm{mM}$ phosphate buffer $\mathrm{pH} 6.8$, stirred for $5 \mathrm{~min}$ at $4{ }^{\circ} \mathrm{C}$, and kept for $1 \mathrm{~h}$ at $4{ }^{\circ} \mathrm{C}$ before centrifugation at $(500 \times g$, 
$30 \mathrm{~min}, 4^{\circ} \mathrm{C}$. The supernatant absorbance was measured using a spectrophotometer (JENWAY $6405 \mathrm{UV} /$ visible, UK) at wavelengths of 525, 545, 565, and $572 \mathrm{~nm}$. MetMb (\%) was calculated using the following equation according to Krzywicki [58]:

$$
\operatorname{MetMb}(\%)=[-2.51(\mathrm{~A} 572 \mid \mathrm{A} 525)+0.8(\mathrm{~A} 545 \mid \mathrm{A} 525)+0.777(\mathrm{~A} 565 \mid \mathrm{A} 525)] \times 100
$$

\section{Lipid Peroxidation Assay}

Lipid peroxidation inhibition (\%) was determined using Niehaus Jr and Samuelsson [59] procedure. Chicken meat filtrate was dissolved in phosphate buffer $(50 \mathrm{mM}, \mathrm{pH} 7)$ and centrifuged at $\left(12,000 \times \mathrm{g}, 60 \mathrm{~min}, 4^{\circ} \mathrm{C}\right)$ to obtain the supernatant. $100 \mu \mathrm{L}$ of the supernatant was added to $2 \mathrm{~mL}$ of TBA, boiled for $30 \mathrm{~min}$, then cooled. The absorbance was estimated at $535 \mathrm{~nm}$ using a spectrophotometer (JENWAY $6405 \mathrm{UV} /$ visible, UK) as compared to control. The inhibition in lipid oxidation (\%) was calculated using the following equation:

$$
\text { Lipid oxidation inhibtion }(\%)=1-\frac{\text { Sample absorbance }}{\text { control absorbance }} \times 100
$$

\section{Total Volatile Basic Nitrogen (TVBN)}

Ten milliliters of chicken meat filtrate was combined with $30 \mathrm{~mL}$ of $5 \%$ Trichloroacetic acid and centrifuged at $3000 \times g$ for $1 \mathrm{~h}$. Five milliliters of the supernatant was pipetted into the Markham apparatus, and $5 \mathrm{~mL}$ of $\mathrm{NaOH}(2 \mathrm{~N})$ was added. The obtained steam was titrated into $15 \mathrm{~mL}$ of standard $\mathrm{HCl} 0.01 \mathrm{~N}$ containing drops of rosolic indicator. The excess acid was then titrated in the receiving flask containing phenolphthalein with standard $\mathrm{NaOH}(0.01 \mathrm{~N})$ to a pale pink end. A technical blank was done using $5 \mathrm{~mL}$ Trichloroacetic acid without sample and titrated as before Idakwo, et al. [60]. The concentration of TVBN (mg N/100 g sample) was calculated as follows:

$$
\operatorname{TVBN}\left(\mathrm{mg} \frac{\mathrm{N}}{100} \mathrm{~g} \text { sample }\right)=\frac{(\mathrm{N})(\mathrm{VB}-\mathrm{VS})(14)(300+\mathrm{W})}{5}
$$

where $\mathrm{VB}=$ the amount of $\mathrm{NaOH}(\mathrm{mL})$ in blank titration, $\mathrm{W}=$ mositure content of sample in $\mathrm{g} / 100 \mathrm{~g}, \mathrm{~N}=$ Standard $\mathrm{NaOH}$ Normality, and vs. = the amount of $\mathrm{NaOH}(\mathrm{mL})$ in the main titration.

\subsubsection{Sensory Evaluation and Color Measurement}

The shearing force of cooked chicken meat cubes enriched with BKH, RKH, and WKH at different levels $(200,400$, and $800 \mu \mathrm{g} / \mathrm{g}$ ) was measured by a texture analyzer (Compac100 model, Sun Scientific Co., Tokyo, Japan) using the method of Piga, et al. [61]. The meat samples were coded with three random digits, and were served to evaluation by eight experienced panelists at Zagazig University, Egypt. Each panelist evaluated five attributes; tenderness, juiciness, taste, aroma, and overall acceptability in each sample at interval of $(0,10,20$, and 30) days of cold storage by using a 9-point hedonic scale $(9=$ like extremely, and $1=$ dislike extremely). Samples with scores below 5 were deemed unacceptable.

The color parameters $\left(L^{*}, a^{*}\right.$ and $\left.b^{*}\right)$ of chicken meat color were evaluated by a color analyzer (Hunter Lab color Flex EZ, USA). The L* expressed [(0) whiteness to (100) darkness], $\mathrm{a}^{*}$ expressed [(-) redness to $(+)$ greenness] and $\mathrm{b}^{*}$ value observed [yellowness $(+)$ to blueness $(-)]$ and total color change $(\Delta \mathrm{E})$ was calculated from Equation (10). Chicken meat samples were placed into analyzer flask, and then the colorimeter sensor measured color attributes [62]:

$$
\Delta \mathrm{E}=\sqrt{\left(\mathrm{L}_{2}-\mathrm{L}_{1}\right)^{2}+\left(\mathrm{a}_{2}-\mathrm{a}_{1}\right)^{2}}+\left(\mathrm{b}_{2}-\mathrm{b}_{1}\right)^{2}
$$

\subsubsection{Microbial Analysis}

The microbial load of raw chicken meat was estimated according to Saad, et al. [63]. The meat filtrate was dissolved in sterilized peptone buffer $(1: 9 w / v)$ in a screw bottle 
and stirred for $10 \mathrm{~min}$ to prepare $10^{-1}$ concentration. One milliliter of the suspension was used in preparing decimal dilutions down to $10^{-5}$. One $\mathrm{mL}$ of each dilution was added in one-use Petri-dishes, then the specific media was added [64]. After $24 \mathrm{~h}$ incubation at $30^{\circ} \mathrm{C}$, the total bacterial count (TBC) was enumerated on plate count agar (PCA). Additionally, PCA was used for counting psychrophilic bacteria count (PBC) after incubating for 10 days at $7^{\circ} \mathrm{C}$. Microbiological results were converted to logarithms (CFU/g) [65-67].

\subsection{Statistical Analysis}

All tests were carried out in triplicate. The means of the experimental data triplicates were subjected to the analysis of variance (ANOVA) test with a significance level of $5 \%$, followed by LSD test to investigate the significant differences using Data analysis in Microsoft Excel with Microsoft Office version 2019.

\section{Results and Discussion}

\subsection{Physico-Chemical Characterization of the Hydrolysates}

\subsubsection{Chemical Composition of Protein Isolates and Hydrolysates}

The proximate compositions of white, red, and black kidney bean plants, protein isolates, and hydrolysates are shown in Table 1. Black kidney bean has higher protein contents in the different forms, total, isolate and hydrolysates (T, I, and H), amounting to 24.5, 91 , and $88 \%$, respectively. Alternatively, red kidney beans had the highest carbohydrate content in the different forms ( $\mathrm{T}$, I and $\mathrm{H})$, recording 65.1, 35.4, and 8.7\%, respectively. Ash content was, however, highest in all forms of white kidney bean (T, I, and $H$ ), reaching 5.1, 7.2, and 9.2\%, respectively. Evangelho, et al. [68] found that black bean proximate composition was $23.1 \%$ protein, $4.3 \%$ ash, $1.2 \%$ fat, $71.4 \%$ of total carbohydrate, and protein isolate was $81.6 \%$ protein, and $11.4 \%$ carbohydrates. Generally, ash content increased with protein isolation or hydrolysis by Alcalase, but protein content significantly increased by $73-75 \%$ in isolate forms (BKI, RKI, and WKI), and slightly decreased in the hydrolysates forms (BKH, RKH, and $\mathrm{WKH})$, probably due to the increments in ash content by $11-21 \%$. A similar reduction in protein content of black bean protein was observed in a previous study after $2 \mathrm{~h}$-Alcalase hydrolysis. These reductions were associated with an increase in the ash content of black bean protein hydrolysates, possibly as a result of supplying inorganic alkali to keep the $\mathrm{pH}$ constant during hydrolysis [68]. A similar reduction in protein content accompanied by an increase in ash content was observed in Alcalase-hydrolyzed chickpea protein [69].

Table 1. Chemical composition of total seed material (T), protein isolate (I) and protein hydrolysate $(\mathrm{H})$, isolated from black, red, and white kidney bean seeds.

\begin{tabular}{|c|c|c|c|c|c|c|c|c|c|}
\hline \multirow{2}{*}{$\begin{array}{c}\text { Chemical } \\
\text { Composition (\%) } \\
\text { Material Status }\end{array}$} & \multicolumn{3}{|c|}{ Black Kidney Bean } & \multicolumn{3}{|c|}{ Red Kidney Bean } & \multicolumn{3}{|c|}{ White Kidney Bean } \\
\hline & $\mathbf{T}$ & I & $\mathbf{H}$ & $\mathbf{T}$ & I & $\mathbf{H}$ & $\mathbf{T}$ & $\mathbf{I}$ & $\mathbf{H}$ \\
\hline Protein & $24.5 \pm 0.1^{\mathrm{c}}$ & $91 \pm 1.1^{\mathrm{a}}$ & $88 \pm 0.7^{\mathrm{ab}}$ & $22.7 \pm 0.7^{\mathrm{cd}}$ & $88.9 \pm 1.2^{\mathrm{ab}}$ & $85 \pm 1^{\mathrm{b}}$ & $21.3 \pm 0.6^{\mathrm{d}}$ & $85 \pm 0.9^{b}$ & $82 \pm 0.6^{b c}$ \\
\hline Carbohydrates & $62.1 \pm 0.3^{a b}$ & $32.5 \pm 0.4^{c}$ & $4.7 \pm 0.1^{\mathrm{e}}$ & $65.1 \pm 0.8^{a}$ & $36.7 \pm 0.8^{b}$ & $8.7 \pm 0.2^{d}$ & $64.2 \pm 0.8^{\mathrm{a}}$ & $37.2 \pm 0.5^{b}$ & $8.3 \pm 0.1^{\mathrm{d}}$ \\
\hline Fat & $2.1 \pm 0.1^{\mathrm{b}}$ & ND & ND & $2.5 \pm 0.1^{\mathrm{ab}}$ & ND & ND & $3.1 \pm 0.1^{\mathrm{a}}$ & ND & ND \\
\hline Ash & $4.5 \pm 0.3^{\mathrm{d}}$ & $6.4 \pm 0.1^{\mathrm{b}}$ & $7.3 \pm 0.2^{\mathrm{ab}}$ & $4.19 \pm 0.2^{\mathrm{d}}$ & $5.7 \pm 0.1^{c}$ & $6.5 \pm 0.1^{\mathrm{b}}$ & $5.1 \pm 0.2^{\mathrm{cd}}$ & $7.2 \pm 0.2^{\mathrm{ab}}$ & $9.4 \pm 0.1^{\mathrm{a}}$ \\
\hline Moisture & $5.8 \pm 0.1^{\mathrm{b}}$ & $3.1 \pm 0.1^{\mathrm{cd}}$ & ND & $6.14 \pm 0.2^{\mathrm{ab}}$ & $3.5 \pm 0.1^{\mathrm{c}}$ & $0.88 \pm 0.03^{\mathrm{e}}$ & $6.45 \pm 0.1^{\mathrm{a}}$ & $1.5 \pm 0.01^{\mathrm{d}}$ & $0.98 \pm 0.02^{e}$ \\
\hline
\end{tabular}

$\mathrm{ND}$, not detected. All values are expressed as means \pm SD; Means with different lowercase letters in the same row indicate significant differences at $p \leq 0.05$ by LSD. T is the total material. I is the protein isolate. $\mathrm{H}$ (protein hydrolysate) is obtained after 30-min hydrolysis with Alcalase at $37^{\circ} \mathrm{C}$.

\subsubsection{SDS-PAGE Electrophoretic Pattern}

SDS-PAGE electropherogram of BKI, RKI, and WKI showed in lanes 1, 2, and 3, respectively (Figure 1). Seventeen bands were detected in lanes (1-3) with molecular weights in the range 11-135 kD, referring to similar protein patterns in the three cultivars of kidney beans. Storage proteins, i.e., vicilin (7S), and phaseolin (8S), were found within the molecular weights between $40-75 \mathrm{kD}$. The bands representing phaseolin (40-48 kD), seem more intense than those representing vicilin in accordance with Los, et al. [32], indicating that phaseolin was the most abundant protein of the common bean. These bands 
were relatively the least affected by the 30-min Alcalase hydrolysis as manifested in the electrophoretic pattern of $\mathrm{BKH}, \mathrm{RKH}$, and $\mathrm{WKH}$ in lanes 4, 5, and 6, respectively. Extending the Alcalase hydrolysis time to $60 \mathrm{~min}$ led to the disappearance of these bands (data not shown). The observed resistance of phaseolin to enzymatic hydrolysis in the opposite to vicilin, the total disappearance of bands representing 7S (vicilin) but not phaseolin bands, which relatively resisted enzymatic hydrolysis. Likewise, the $42-47 \mathrm{kD}$ bands referring to phaseolin were visualized in SDS-PAGE profiles of black bean protein isolate [70] after $2 \mathrm{~h}$ pepsin hydrolysis while higher molecular weight bands $(>50 \mathrm{kD})$ disappeared. Similar resistance of phaseolin was noticed after six $\mathrm{h}$ pepsin hydrolysis of white kidney protein isolate [21]. The observed higher intensity of phaseolin bands in BKH and RKH than WKH might have originated from the higher phenolic content in black and kidney beans, as de Toledo, et al. [71] mentioned.

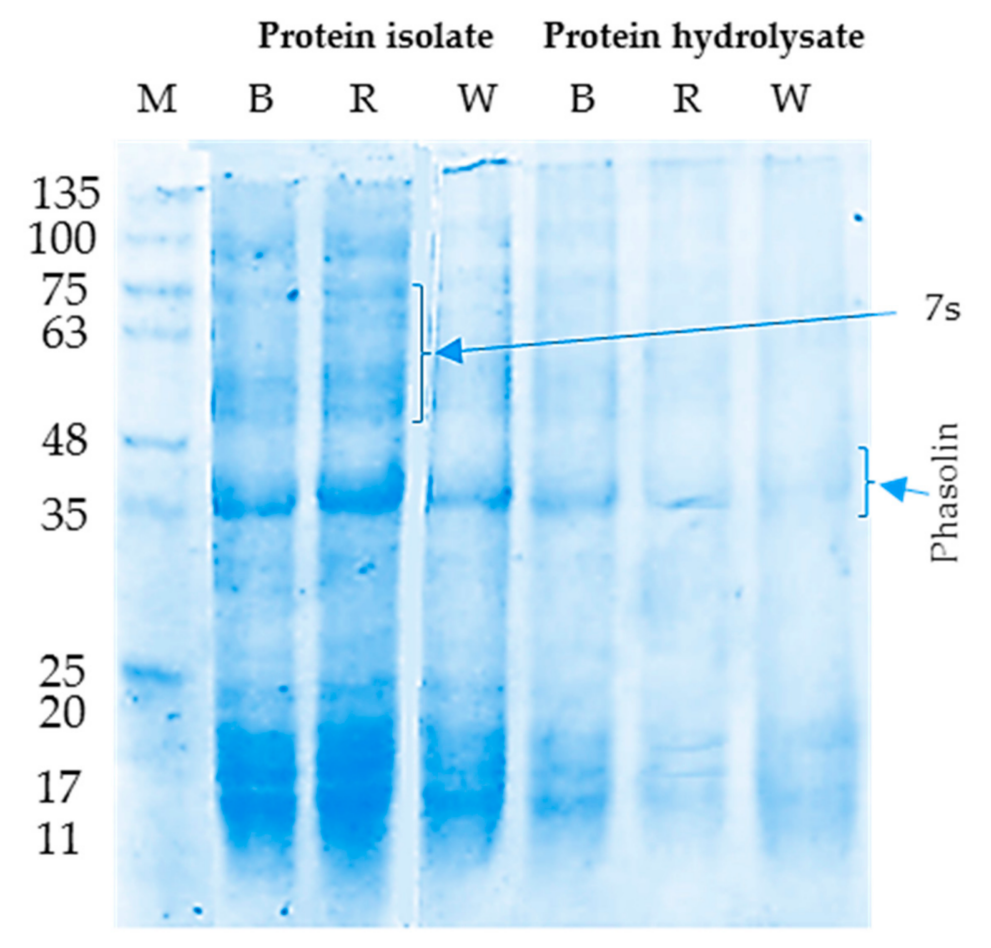

Figure 1. SDS-PAGE profile: (Lanes, 1-3) are for protein isolates and lanes 4-6 for protein hydrolysates (30 min Alcalase hydrolysis at $37^{\circ} \mathrm{C}$ ), isolated from black (B), red (R), and white (W) kidney bean seeds.M, molecular marker.

\subsubsection{Degree of Hydrolysis (DH)}

The data in Figure 2A show the hydrolysis degree of black, red, and white kidney bean protein isolates after subjection to Alcalase for $60 \mathrm{~min}$ at $37 \mathrm{C}$. The DH was significantly $(p \leq 0.05)$ increased with hydrolysis time but not significant differences between $\mathrm{DH}$ values after 30 and $60 \mathrm{~min}$. The highest DH of BKH, RKH, and WKH were obtained after $30 \mathrm{~min}$, reaching 29,27 , and $25 \%$. So, the $\mathrm{BKH}$ exhibited the highest $\mathrm{DH}$ with about a $14 \%$ relative increase over WKH and RKH. Similar results were obtained by Saad, et al. [21] who found that $\mathrm{DH}$ of kidney bean protein isolate was $33 \%$ after hydrolysis with pepsin $1 \%$ for $6 \mathrm{~h}$. In addition, Abdel-Hamid, et al. [72] found that camel whey protein isolates was hydrolyzed by $27 \%$ by Alcalase after $4 \mathrm{~h}$. Furthermore, do Evangelho, et al. [70] found the highest $\mathrm{DH}=27 \%$ of pepsin black bean protein hydrolysate achieved after $120 \mathrm{~min}$. Moreover, the highest DH (75\%) when Bumrungsart and Duangmal [36] used Flavourzyme ${ }^{\circledR}(6 \%$, $360 \mathrm{~min}$ ) to hydrolyze black gram bean protein isolate. The obtained $\mathrm{DH}$ in the range of previous studies. 

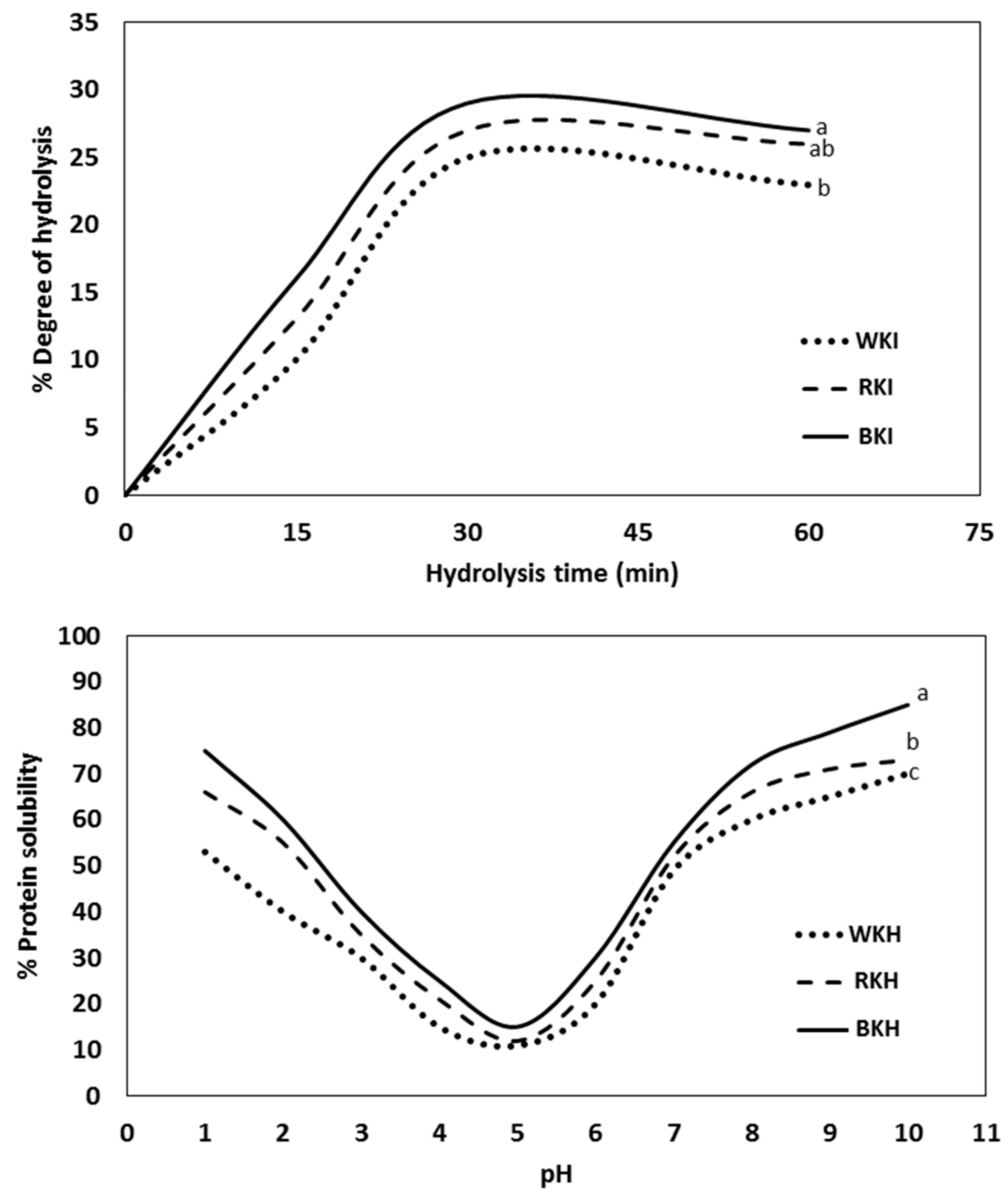

B

Figure 2. Hydrolysis degree (A) and pH-solubility curves (B) of black, red and white kidney seed protein hydrolysates $(\mathrm{BKH}, \mathrm{RKH}$ and $\mathrm{WKH})$ prepared by 30 min hydrolysis with Alcalase at $37^{\circ} \mathrm{C}$ and $\mathrm{pH}$ 6. Means with different lowercase letters indicate significant differences at $p \leq 0.05$ by LSD.

\subsection{4. $\mathrm{pH}$-Protein Solubility}

The inclusion of functional proteins in food formulations depends on its solubility, which affects other protein functional properties, such as foaming and emulsifying [73]. The isoelectric $\mathrm{pH}$ (lowest solubility) of $\mathrm{WKH}, \mathrm{RKH}$, and $\mathrm{BKH}$ ranged 4-6 (Figure 2B), which is not different from the intact mother protein. Generally, the solubility of protein significantly increased $p \leq 0.05$ when the $\mathrm{pH}$ moves away from the isoelectric point. The solubility of WKH, RKH, and BKH after 30 min hydrolysis by Alcalase was $(53,66$, and $75 \%)$ at $\mathrm{pH} 2$ and recorded the highest levels at $\mathrm{pH} 10$, i.e., 70,75 , and $90 \%$, respectively. The order of solubility levels $\mathrm{BKH}>\mathrm{RKH}>\mathrm{WKH}$, is a reflection of the same order of the degree of hydrolysis, which understandably enhances it. The observed higher solubility at the basic side than the acidic side agrees with Los, et al. [32] who reported $35.13 \%$ solubility values of carioca bean and soybean protein hydrolysate at $\mathrm{pH} 3.0$ against $100 \%$ at $\mathrm{pH} 7.0$. Osman, et al. [74] found that white kidney bean protein pepsin hydrolysate has maximum solubility at $\mathrm{pH} 10$ with $82 \%$, also, Wahdan and Saad [75] found that white kidney bean protein papain hydrolysate has $78 \%$ solubility at $\mathrm{pH} 10$.

\subsubsection{Functional Properties}

The data in Table 2 show the functional properties of the hydrolysates; $\mathrm{BKH}, \mathrm{RKH}$ and $\mathrm{WKH}$, after $30 \mathrm{~min}$ Alcalase-hydrolysis. The BKH has the highest water holding capacity (WHC), recording about a 30\% solubility increase over the original intact proteins (BKPI). 
The other two hydrolysates, $\mathrm{RKH}$ and $\mathrm{WKH}$, recoded lower relative solubility increases over their intact protein (RKI and WKI), amounting to $15 \%$, and 20\%, respectively. The oil absorbance capacity (OAC) of $\mathrm{BKH}$ recorded the highest significant $(p<0.05)$ increase of $35 \%$ over the intact protein (BKI), against only $20 \%$ and $25 \%$ relative increases in the case of $\mathrm{RKH}$, and WKH over their intact mother forms. On the other hand, the three hydrolysates showed higher foaming stability at $\mathrm{pH} 5$, i.e., 88, 75, and $50 \mathrm{~min}$ for $\mathrm{BKH}$, RKH, and $\mathrm{WKH}$, respectively, with relative increases about $25-40 \%$ over the respective intact protein forms, i.e., BKI, RKI and WKI. Similar results were reported by Wani, et al. [47], who found higher forming stability of black gram protein hydrolysate at $\mathrm{pH} 5$ than $\mathrm{pH} 3$ and 7 . The foaming stability index (FSI) of protein hydrolysates was in the range of 15.7-89.0 $\mathrm{min}$. Generally, protein hydrolysates have higher ESI at $\mathrm{pH} 3$ and 5, against lower $\mathrm{pH} 7$. In addition, Eckert, et al. [76] stated that foaming capacity (FC) of fava bean protein pepsinhydrolysate increased by $74 \%$ at $\mathrm{pH} 5$ and $50 \%$ at $\mathrm{pH} 7$ over the intact protein. In addition, the oil holding capacity (OHC) increased from 6.12 to $8.21 \% \mathrm{~g} / \mathrm{g}$ by pepsin hydrolysis. Generally, the enzymatic hydrolysis significantly increased the functional properties of protein isolates. Faustino, et al. [27] stated that the inclusion of high solubility proteins in foods enhances the technological properties in supplemented foods, and it was required in many functional food applications.

Table 2. Functional properties of black, red and white kidney bean protein hydrolysate $(\mathrm{BKH}, \mathrm{RKH}$, and $\mathrm{WKH}$ ) obtained after $30 \mathrm{~min}$ Alcalase hydrolysis at $37^{\circ} \mathrm{C}$.

\begin{tabular}{|c|c|c|c|c|c|c|}
\hline \multirow{3}{*}{$\begin{array}{c}\text { Protein } \\
\text { Hydrolysate }\end{array}$} & \multirow{3}{*}{$\begin{array}{c}\text { HT } \\
\text { (min) }\end{array}$} & \multicolumn{5}{|c|}{ Functional Properties } \\
\hline & & \multirow{2}{*}{$\begin{array}{l}\text { WAC } \\
\text { (g/g) }\end{array}$} & \multirow{2}{*}{$\begin{array}{r}\text { OAC } \\
(g / g)\end{array}$} & \multicolumn{3}{|c|}{ FS (min) } \\
\hline & & & & pH 3 & pH 5 & pH 7 \\
\hline \multirow{2}{*}{$\mathrm{BKH}$} & 0 & $6.9 \pm 0.5^{\mathrm{d}}$ & $6.8 \pm 0.2^{\mathrm{d}}$ & $23 \pm 0.1^{c}$ & $65 \pm 0.3^{c}$ & $26 \pm 0.6^{c}$ \\
\hline & 30 & $9.4 \pm 0.2^{\mathrm{a}}$ & $10.5 \pm 0.6^{\mathrm{a}}$ & $27 \pm 0.3^{\mathrm{a}}$ & $88 \pm 0.9^{a}$ & $30 \pm 0.8^{a}$ \\
\hline \multirow{2}{*}{$\mathrm{RKH}$} & 0 & $6.7 \pm 0.4^{\mathrm{de}}$ & $6.5 \pm 0.3$ de & $20 \pm 0.8^{\mathrm{d}}$ & $44 \pm 0.8^{\mathrm{e}}$ & $23 \pm 0.2^{d}$ \\
\hline & 30 & $8.2 \pm 0.8^{b}$ & $9.3 \pm 0.1^{b}$ & $25 \pm 0.6^{b}$ & $75 \pm 0.7^{b}$ & $28 \pm 0.5^{b}$ \\
\hline \multirow{2}{*}{ WKH } & 0 & $6.1 \pm 0.3^{\mathrm{e}}$ & $6.0 \pm 0.1^{\mathrm{e}}$ & $18 \pm 0.9^{\mathrm{e}}$ & $29 \pm 0.1^{\mathrm{f}}$ & $21 \pm 0.4^{\mathrm{e}}$ \\
\hline & 30 & $7.2 \pm 0.1^{\mathrm{c}}$ & $8.1 \pm 0.2^{c}$ & $22 \pm 0.7^{\mathrm{cd}}$ & $50 \pm 0.9^{d}$ & $25 \pm 0.3^{\mathrm{cd}}$ \\
\hline
\end{tabular}

$\overline{\text { HT, hydrolysis time; WAC, water-absorbing capacity; OAC, oil-absorbing capacity; FS, foaming stability. All }}$ values are expresses as means $\pm \mathrm{SD}$. Means with different lowercase letters in the same column indicate significant differences at $p \leq 0.05$ by LSD.

\subsubsection{Total Phenolic, Flavonoids, and Anthocyandins Content}

Table 3 presents the contents of total phenolic, flavonoids, and anthocyanins in the different protein hydrolysates. Generally, the contents of these compounds significantly increased in a concentration-dependent manner. The BKH $(800 \mu \mathrm{g} / \mathrm{mL})$ recorded higher values of phenolic, flavonoids, and anthocyanins amounting to $63.3 \mathrm{mg} \mathrm{GAE} / \mathrm{g}, 16.2 \mathrm{mg}$ $\mathrm{QE} / \mathrm{g}$, and $0.6 \mathrm{mg} / \mathrm{mL}(800 \mu \mathrm{g} / \mathrm{mL})$, respectively. The levels of phenolic and flavonoids were not significantly different among the three protein hydrolysates $(\mathrm{BKH}, \mathrm{RKH}$ and WKH) but the levels of anthocyanin in RKH and WKH were significantly $(p \leq 0.05)$ lower than in BKH, recording 91, and $45 \%$ reductions, respectively. Sarker, et al. [77] found that the polyphenols contents in dark red bean protein hydrolysate were $44.3 \mathrm{mg} \mathrm{GAE} / \mathrm{g}$, and $38.89 \mathrm{mg}$ GAE/g Roy, et al. [43]. The physicochemical properties of protein may affected by protein-phenolic interaction; the peptide activity may increase by blocking some amino acid side chains, thereby increasing the bioavailability and activity of polyphenols [78]. Polyphenols become entrapped in the peptide fragments and the enzyme hydrolyzes the protein, and becomes bound with polyphenols. Therefore, the polyphenols will be released and their free content will increase [79]. Additionally, it was found that alcalase hydrolysis of rice bran protein for 10 min was enough to extract all the bound phenolic acids [80]. 
Table 3. Total phenolic, total flavonoids and total anthocyanin content in different concentrations of black, red and white kidney bean protein hydrolysates (BKH, RKH, and WKH) obtained after 30 min Alcalase hydrolysis at $37^{\circ} \mathrm{C}$.

\begin{tabular}{|c|c|c|c|c|c|c|c|c|c|}
\hline \multirow{2}{*}{$\begin{array}{l}\text { Concn } \\
(\mu \mathrm{g} / \mathrm{mL})\end{array}$} & \multicolumn{3}{|c|}{$\begin{array}{l}\text { Total Phenolic } \\
\text { (mg GAE/g) }\end{array}$} & \multicolumn{3}{|c|}{$\begin{array}{l}\text { Total Flavonoids } \\
\text { (mg QE/g) }\end{array}$} & \multicolumn{3}{|c|}{$\begin{array}{c}\text { Total Anthocyanin } \\
(\mu \mathrm{g} / \mathrm{mL})\end{array}$} \\
\hline & ВКН & RKH & WKH & ВКН & RKH & WKH & ВКН & RKH & WKH \\
\hline 50 & $11.2 \pm 0.1^{\mathrm{e}}$ & $9.5 \pm 0.5^{\mathrm{e}}$ & $7.2 \pm 0.9^{\mathrm{e}}$ & $6.5 \pm 0.1^{\mathrm{e}}$ & $5.2 \pm 0.1^{\mathrm{e}}$ & $6.2 \pm 0.3^{d}$ & $1.90 \pm 0.1^{\mathrm{d}}$ & $1.02 \pm 0.01^{\mathrm{e}}$ & $0.11 \pm 0.02^{\mathrm{d}}$ \\
\hline 100 & $17.4 \pm 0.5^{\mathrm{d}}$ & $15.4 \pm 0.4^{\mathrm{d}}$ & $12.4 \pm 0.8^{\mathrm{d}}$ & $8.7 \pm 0.2^{\mathrm{d}}$ & $7.1 \pm 0.3^{\mathrm{d}}$ & $8.1 \pm 0.2^{\mathrm{c}}$ & $2.56 \pm 0.2^{c}$ & $1.56 \pm 0.09 \mathrm{~d}$ & $0.25 \pm 0.01^{c}$ \\
\hline 200 & $31.6 \pm 0.7^{c}$ & $28.7 \pm 0.3^{c}$ & $24.3 \pm 0.6^{c}$ & $11.9 \pm 0.1^{\mathrm{c}}$ & $10 \pm 0.2^{c}$ & $12.2 \pm 0.4^{b}$ & $4.5 \pm 0.2^{b c}$ & $2.45 \pm 0.1^{c}$ & $0.30 \pm 0.01^{b c}$ \\
\hline 400 & $39.6 \pm 1.1^{b}$ & $35.5 \pm 0.2^{b}$ & $33.8 \pm 0.7^{b}$ & $14.1 \pm 0.4^{b}$ & $12.5 \pm 0.5^{b}$ & $13.2 \pm 0.7^{\mathrm{ab}}$ & $4.77 \pm 0.3^{b}$ & $2.89 \pm 0.1^{b}$ & $0.34 \pm 0.03^{b}$ \\
\hline 800 & $63.3 \pm 1.5^{\mathrm{a}}$ & $60.6 \pm 0.9^{a}$ & $55.8 \pm 1.2^{\mathrm{a}}$ & $16.2 \pm 0.8^{a}$ & $15.8 \pm 0.3^{a}$ & $14.4 \pm 0.6^{\mathrm{a}}$ & $5.6 \pm 0.4^{\mathrm{a}}$ & $3.12 \pm 0.2^{a}$ & $0.8 \pm 0.04^{\mathrm{a}}$ \\
\hline
\end{tabular}

All values are expressed as means \pm SD. Means with different lowercase letters in the same column indicate significant differences at $p \leq 0.05$ by LSD.

\subsubsection{Antioxidant Activity}

DPPH estimated the scavenging activity of protein hydrolysates and the results are presented in Figure 3A. The results herein showed that BKH $(800 \mu \mathrm{g} / \mathrm{mL})$ significantly scavenged a high level of DPPH radical (95\%). The concentration dependence of this phenomenon confirms the role of the phenolic compounds in this activity. The antioxidant activity of $\mathrm{WKH}, \mathrm{RKH}$, and $\mathrm{BKH}$ as determined by $\beta$-Carotene/linoleic acid bleaching, indicates that the inhibition in linoleic acid oxidation was increased with by the hydrolysate in a concentration-dependent manner. Figure 3B shows that BKH $(800 \mu \mathrm{g} / \mathrm{mL})$ has the highest values with $88 \%$ while RKH and WKH came in the second-order with 82 and $79 \%$ inhibition, respectively. The higher scavenging and antioxidant activity of this BKH hydrolysate may be attributed to the relatively high total polyphenols content in this protein hydrolysate. It was recently found that white kidney bean pepsin hydrolysate exhibited antioxidant activity with $85 \%$, and white kidney bean papain hydrolysate exhibited $89 \%$, respectively [21,75]. Furthermore, the dark red bean protein hydrolysate exhibited stronger antioxidant activity than the protein isolate and higher than ascorbic acid (AA), which is commercially used in the food industry [77]. The antioxidant mechanism of tested peptides depends on their content of aromatic amino acids donating an electron or transferring hydrogen to the free radicals for stability. Whereas, the acidic amino acids maintain the stability of the free radicals by giving a proton through the $\mathrm{NH} 2$ and $\mathrm{COOH}$ side chains [81]. Antioxidant peptides have critical importance in the food industry, where they keep the product quality by preventing the oxidation of proteins, lipids, and nucleic acids [82].

\subsubsection{Antimicrobial Activity of the Hydrolysates}

Antibacterial

Table 4 and Figure 4 show the inhibition zone diameters (IZDs) of some pathogenic bacteria when subjected to $\mathrm{BKH}, \mathrm{RKH}$, and $\mathrm{WKH}$ at different concentrations $(50,100$, 200,400 , and $800 \mu \mathrm{g} / \mathrm{mL}$ ). BKH concentrations induced the largest IZDs in the range of $10-33 \mathrm{~mm}$ followed by RKH in the range of $12-31 \mathrm{~mm}$. The G+ and G- bacteria; S. pyogenes, and E. coli, were the most sensitive to the protein hydrolysates, exhibiting 25 and $33 \mathrm{~mm}$ IZDs when subjected to $800 \mu \mathrm{g} / \mathrm{mL}$. Alternatively, the G+ and G- bacteria, L. monocytogenes, C. jejuni were most resistant to the studied hydrolysates, recording only 26 and $21 \mathrm{~mL}$ IZDs, respectively. The lower IZDs observed in the resistant G- bacteria compared to the G+ ones might have resulted from the lipopolysaccharide layer in the membranes, which act as a block banning the antibacterial agents' penetration. Besides, the presence of some enzymes in the periplasmic space of the G- bacteria may be capable of annealing foreign molecules [83]. 


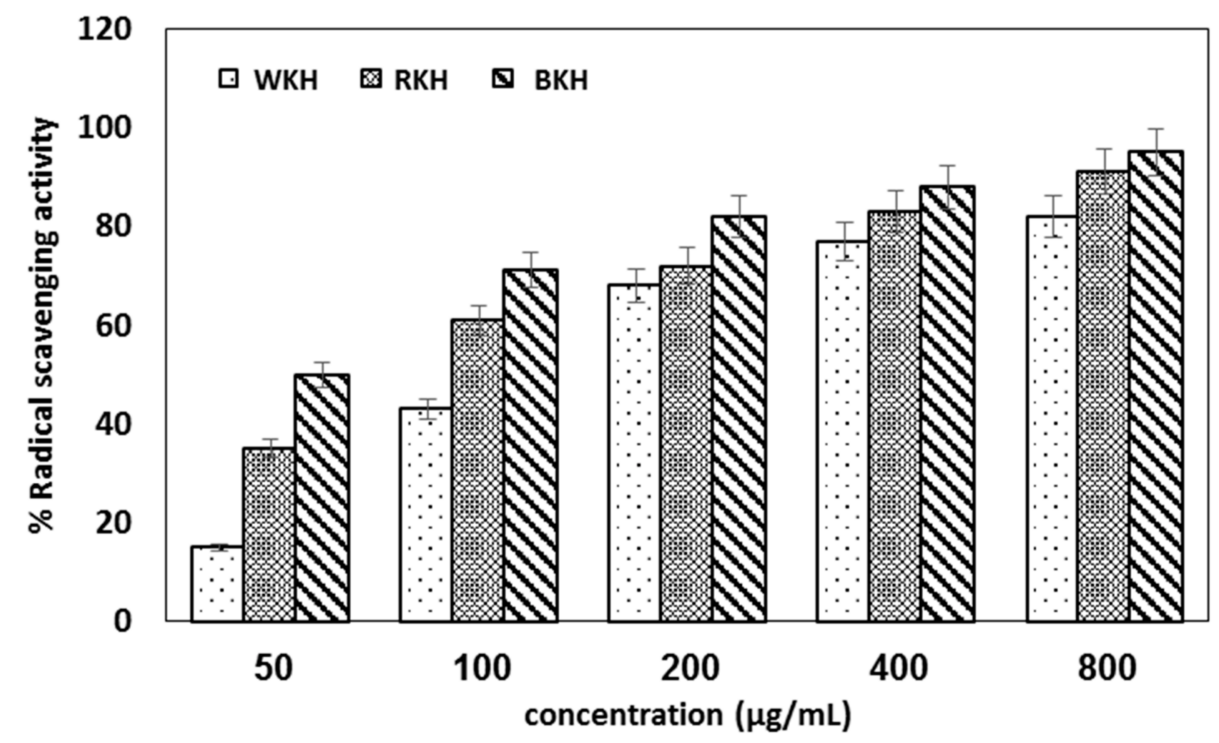

A

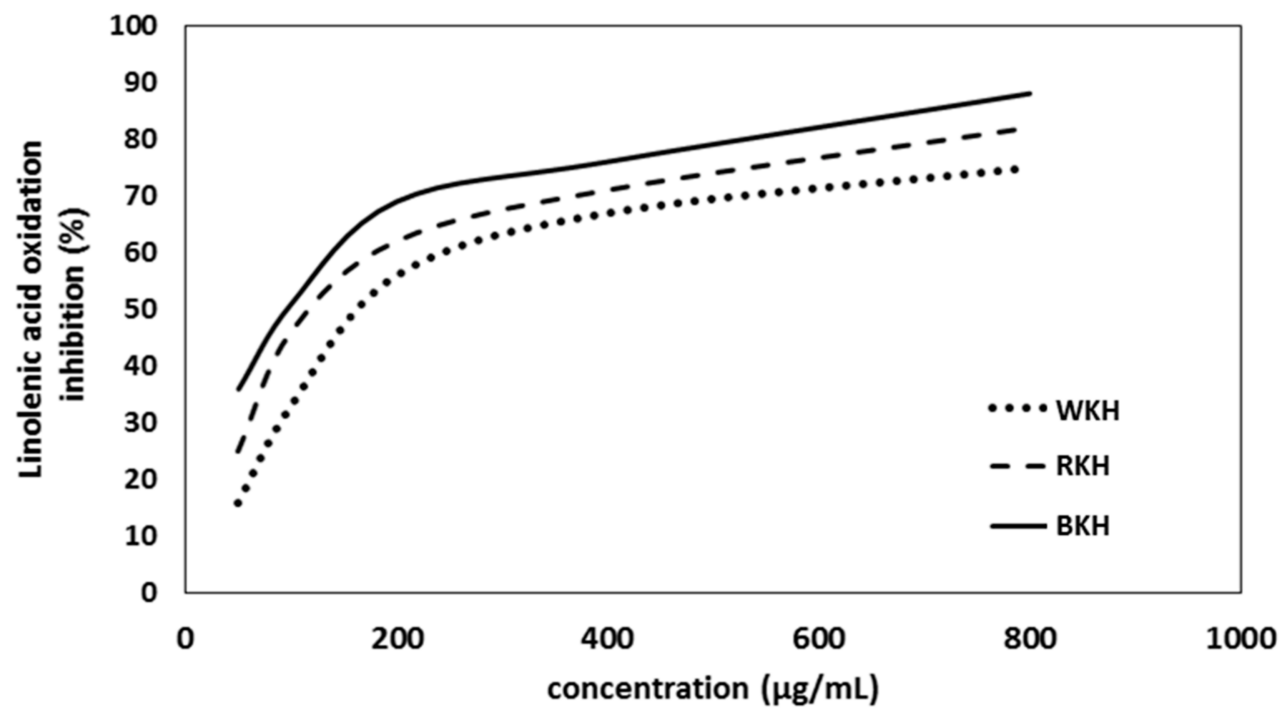

Figure 3. Free radical scavenging activity (A) and antioxidant activity (B) of protein Alcalase hydrolysates of black, red and white kidney bean protein (BKH, RKH, WKH). Protein Alcalase hydrolysis was conducted at $37^{\circ} \mathrm{C}, \mathrm{pH} 6$ for $30 \mathrm{~min}$. Means with different lowercase letters indicate significant differences at $p \leq 0.05$ by LSD.

Table 4. Antibacterial activity against gram-positive and gram-negative bacterial strains (expressed as the diameter of the inhibition zones) of different concentrations $(50-800 \mu \mathrm{g} / \mathrm{mL})$ of black, red and white kidney bean protein hydrolysate $(\mathrm{BKH}$, $\mathrm{RKH}$ and $\mathrm{WKH}$ ) obtained after $30 \mathrm{~min}$ Alcalase hydrolysis at $37^{\circ} \mathrm{C}$.

\begin{tabular}{|c|c|c|c|c|c|c|c|c|c|c|c|c|c|c|c|}
\hline \multirow{2}{*}{ Bacteria } & \multicolumn{5}{|c|}{ BKH } & \multicolumn{5}{|c|}{ RKH } & \multicolumn{5}{|c|}{ WKH } \\
\hline & 50 & 100 & 200 & 400 & 800 & 50 & 100 & 200 & 400 & 800 & 50 & 100 & 200 & 400 & 800 \\
\hline \multicolumn{16}{|l|}{ G+ } \\
\hline B. cereus & $15 \pm 0.0^{a b}$ & $21 \pm 0.14^{\mathrm{b}}$ & $23 \pm 0.21^{b}$ & $26 \pm 0.16^{b}$ & $28 \pm 0.11^{b}$ & $14 \pm 0.11^{a b}$ & $19 \pm 0.15^{b}$ & $22 \pm 0.14^{b}$ & $24 \pm 0.12^{b}$ & $27 \pm 0.21^{b}$ & - & $15 \pm 0.25^{b}$ & $21 \pm 0.21^{\mathrm{ab}}$ & $23 \pm 0.12^{b}$ & $27 \pm 0.33^{b}$ \\
\hline $\begin{array}{l}\text { L. mono- } \\
\text { cytogenes }\end{array}$ & $14 \pm 0.11^{b}$ & $19 \pm 0.22^{c}$ & $21 \pm 0.14^{\mathrm{c}}$ & $25 \pm 0.14^{b c}$ & $27 \pm 0.17^{b c}$ & $13 \pm 0.34^{b}$ & $18 \pm 0.19 b c$ & $21 \pm 0.15^{b c}$ & $23 \pm 0.18^{b c}$ & $26 \pm 0.28 \mathrm{bc}$ & - & $13 \pm 0.14^{c}$ & $19 \pm 0.15^{b}$ & $22 \pm 0.14^{b c}$ & c $26 \pm 0.14$ bc \\
\hline S. pyogenes & $16 \pm 0.14^{\mathrm{a}}$ & $23 \pm 0.21^{\mathrm{a}}$ & $26 \pm 0.19^{\mathrm{a}}$ & $29 \pm 0.15^{\mathrm{a}}$ & $33 \pm 0.0^{\mathrm{a}}$ & $15 \pm 0.22^{\mathrm{a}}$ & $22 \pm 0.23^{a}$ & $24 \pm 0.19^{\mathrm{a}}$ & $27 \pm 0.23^{\mathrm{a}}$ & $31 \pm 0.19^{a}$ & - & $17 \pm 0.16^{\mathrm{a}}$ & $22 \pm 0.17^{\mathrm{a}}$ & $25 \pm 0.18^{\mathrm{a}}$ & $30 \pm 0.25^{a}$ \\
\hline \multicolumn{16}{|l|}{ G- } \\
\hline E. coli & $13 \pm 0.18^{b c}$ & $18 \pm 0.15^{\mathrm{cd}}$ & $20 \pm 0.0^{c d}$ & $23 \pm 0.22^{c}$ & $25 \pm 0.23^{c}$ & - & $16 \pm 0.14^{c}$ & $19 \pm 0.22^{c}$ & $21 \pm 0.17^{c}$ & $24 \pm 0.17^{c}$ & - & $12 \pm 0.18^{\mathrm{cd}}$ & $18 \pm 0.19 \mathrm{bc}$ & $=21 \pm 0.19^{c}$ & $25 \pm 0.41^{c}$ \\
\hline C. jejuni & $10 \pm 0.21 \mathrm{~d}$ & $14 \pm 0.12^{\mathrm{e}}$ & $16 \pm 0.21^{\mathrm{e}}$ & $20 \pm 0.23^{\mathrm{e}}$ & $22 \pm 0.12 \mathrm{e}^{\mathrm{e}}$ & - & $12 \pm 0.51^{\mathrm{e}}$ & $15 \pm 0.31^{\mathrm{e}}$ & $18 \pm 0.55^{\mathrm{e}}$ & $20 \pm 0.15^{\mathrm{e}}$ & - & $10 \pm 0.32 \mathrm{e}$ & $13 \pm 0.23^{\mathrm{d}}$ & $18 \pm 0.21^{\mathrm{d}}$ & $21 \pm 0.23^{\mathrm{e}}$ \\
\hline S. typhi & $11 \pm 0.13^{c}$ & $16 \pm 0.21^{\mathrm{d}}$ & $19 \pm 0.32^{\mathrm{d}}$ & $21 \pm 0.22^{d}$ & $23 \pm 0.17^{d}$ & - & $14 \pm 0.14^{\mathrm{d}}$ & $17 \pm 0.32^{\mathrm{d}}$ & $19 \pm 0.21^{\mathrm{d}}$ & $21 \pm 0.14^{\mathrm{d}}$ & & $11 \pm 0.47^{\mathrm{d}}$ & $15 \pm 0.45^{c}$ & $20 \pm 0.33^{\mathrm{cd}}$ & $\mathrm{d} 23 \pm 0.12^{\mathrm{d}}$ \\
\hline
\end{tabular}

All values are expresses as means $\pm \mathrm{SD}$. Means with different lowercase letters in the same column indicate significant differences at $p \leq 0.05$ by LSD. 


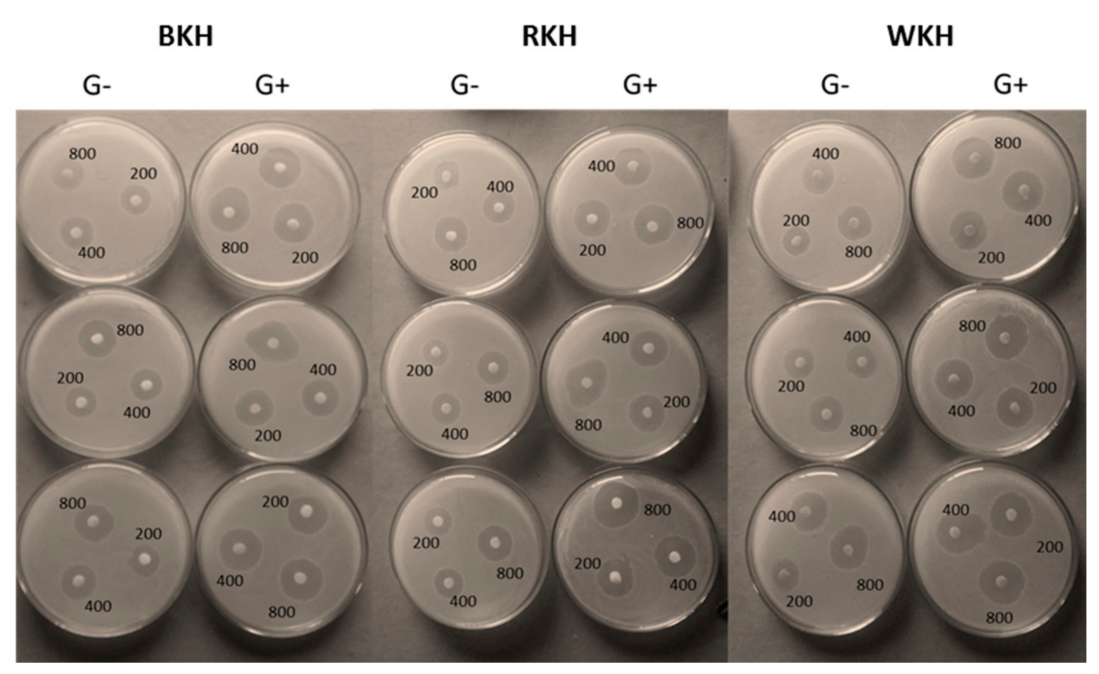

Figure 4. The antibacterial activity of black, red, and white kidney bean protein hydrolysate (BKH, $\mathrm{RKH}$, and $\mathrm{WKH}$ ) obtained by 30 min Alcalase hydrolysis against pathogenic $\mathrm{G}+$, and $\mathrm{G}$ - bacteria.

The data show that BKH has the lowest MIC values $(25-45 \mu \mathrm{g} / \mathrm{mL})$ against the six studied bacteria, representing only less than $50 \%$ and $25 \%$ of the $\mathrm{RKH}$, and $\mathrm{WKH}$ respective values, respectively. At higher concentrations, $\mathrm{BKH}$ could completely inhibit the bacteria recording MBC in the range $50-85 \mu \mathrm{g} / \mathrm{mL}$ against $110-175 \mu \mathrm{g} / \mathrm{mL}$ in the case of WKH. Roy, et al. [43] reported similar levels of IZDs of $20.26 \mathrm{~mm}$ and $19.23 \mathrm{~mm}$, of red kidney beans hydrolysate against Escherichia coli, and Pseudomonas aeruginosa, respectively. Wahdan and Saad [75] found that white kidney bean protein hydrolysate produced by $4 \mathrm{~h}$ papain-hydrolysis inhibited the growth of tested bacteria with IZDs in the range of $70-90 \mu \mathrm{g} / \mathrm{mL}$. The antibacterial action of peptides depends on bacterial species. First, the peptides may electrostatically bind to the bacterial membranes. Therefore, the intercellular structures and processes, such as cell wall synthesis, DNA, RNA, and protein synthesis could be affected and the plasma membrane may be interrupted [84].

\section{Antifunga}

The antifungal activity of white, red, and black Alcalase hydrolysates is presented in Table 5. The IZDs diameters of tested hydrolysates $(50,100,200,400$, and $800 \mu \mathrm{g} / \mathrm{mL}$ ) were in the range of $(9-33 \mathrm{~mm})$ against tested fungi, and in the range of $(8-34 \mathrm{~mm})$ against tested Candida and Rhodotorula. Therefore, there was no distinction of the action of the hydrolsates between fungi and Candida. The most sensitive fungi to the studied hydrolysates were F. equiseti, F. avenaceum, and Candida, C. tropicalis and R. mucilginosa were the most susceptible to the high concentration of kidney bean hydrolysate $(800 \mu \mathrm{g} / \mathrm{mL})$, showing IZDs in the range of 31-33, and 30-34 at $800 \mu \mathrm{g} / \mathrm{mL}$, respectively. On the other hand, the fungi; $A$. niger, and C. gleberta seemed relatively the most resistant recoding IZDs around 23, and $25 \mathrm{~mm}$ against $800 \mu \mathrm{g} / \mathrm{mL}$ of $\mathrm{BKH}$, respectively. The fungal growth was inhibited by BKH, marking a MIC range of $25-45 \mathrm{~mm}$ and eliminated at MFC in the range of 50-90 mm. The MIC and MFC of BKH and were higher than those of RKH and WKH (Table 6). Antimicrobial peptides (AMPs) have different action mechanisms, including the barrel-stave mechanism, which depends on the hydrophobicity of peptides that form pores in the microbial membrane by binding to the hydrophobic groups in the pore. The second is called the toroid pores or wormhole mechanisms or the carpet mechanism, where the polar peptides bind with phospholipids in membranes forming the toroid pores. Therefore, the peptides are deposited on the bilayer surface in a carpet-like fashion, mainly by ionic/electrostatic interactions, leading to cellular membrane destabilization and membrane destruction [85]. Since the protein hydrolysates logically encompass both hydrophobic and hydrophilic peptides, based on the variability of the constituting amino acids, both mechanisms may be functioning at the same time. 
Table 5. Antifungal activity of black kidney, red and white bean protein hydrolysate (BKH, RKH, and WKH) obtained after 30 min Alcalase hydrolysis at $37^{\circ} \mathrm{C}$, against yeast and fungal strains (means $\pm \mathrm{SD}$ ).

\begin{tabular}{|c|c|c|c|c|c|c|c|c|c|c|c|c|c|c|c|}
\hline \multirow{2}{*}{ Microorganisms } & \multicolumn{5}{|c|}{ ВКН } & \multicolumn{5}{|c|}{ RKH } & \multicolumn{5}{|c|}{ WKH } \\
\hline & 50 & 100 & 200 & 400 & 800 & 50 & 100 & 200 & 400 & 800 & 50 & 100 & 200 & 400 & 800 \\
\hline \multicolumn{16}{|c|}{ Fungi } \\
\hline A. niger & $9 \pm \underset{d}{0} 0.0$ & $13 \underset{\mathrm{d}}{ \pm} 0.2$ & $14 \underset{\mathrm{d}}{ \pm} 0.2$ & $18 \pm 0.1$ & $23 \pm 0.2$ & - & $10 \underset{\mathrm{d}}{\mathrm{d}} 0.1$ & $12 \pm 0.3$ & $16 \underset{\mathrm{d}}{ \pm} 0.2$ & $21 \underset{\mathrm{f}}{ \pm} 0.2$ & - & - & $10 \underset{\mathrm{d}}{ \pm} 0.1$ & $13 \underset{\mathrm{d}}{ \pm} 0.2$ & $18 \underset{f}{ \pm} 0.2$ \\
\hline A. fumigatus & $11 \underset{c}{ \pm} 0.1$ & $15 \underset{c}{ \pm} 0.4$ & $16 \underset{\mathrm{bc}}{ \pm} 0.1$ & $21 \underset{\mathrm{d}}{ \pm} 0.3$ & $27 \underset{\mathrm{d}}{ \pm} 0.1$ & - & $12 \underset{c}{ \pm} 0.2$ & $14 \underset{c}{ \pm} 1$ & $19 \underset{c}{ \pm} 0.3$ & $25 \pm 0.4$ & - & - & $12 \underset{\mathrm{bc}}{ \pm} 0.2$ & $16 \underset{c}{ \pm} 0.1$ & $22 \frac{\mathrm{d}}{\mathrm{d}} 0.1$ \\
\hline A. flavus & $10 \underset{c}{ \pm} 0.2$ & $14 \underset{c}{ \pm} 0.3$ & $15 \underset{c}{ \pm} 0.4$ & $20 \underset{\mathrm{de}}{ \pm} 0.1$ & $24 \underset{\mathrm{e}}{ \pm} 0.8$ & - & $13 \underset{b c}{ \pm} 0.6$ & $14 \underset{c}{ \pm} 0.4$ & $18 \underset{\mathrm{cd}}{ \pm} 0.8$ & $22 \underset{\mathrm{e}}{ \pm} 0.7$ & - & - & $11 \underset{c}{ \pm} 0.4$ & $15 \underset{\mathrm{cd}}{ \pm} 0.5$ & $19 \underset{\mathrm{e}}{ \pm} 0.4$ \\
\hline $\begin{array}{l}P . \\
\text { chrysogenum }\end{array}$ & $12 \underset{\mathrm{b}}{ \pm} 0.4$ & $16 \underset{\mathrm{b}}{ \pm} 0.5$ & $17 \underset{\mathrm{b}}{ \pm} 0.8$ & $23 \underset{c}{ \pm} 0.4$ & $29 \underset{c}{ \pm} 0.7$ & - & $14 \underset{\mathrm{b}}{ \pm} 0.4$ & $15 \underset{\mathrm{b}}{ \pm} 0.5$ & $21 \underset{\mathrm{bc}}{ \pm} 0.7$ & $27 \underset{c}{ \pm} 0.3$ & - & - & $13 \underset{\mathrm{b}}{ \pm} 0.5$ & $18 \underset{\mathrm{bc}}{ \pm} 0.1$ & $24 \underset{c}{ \pm} 0.5$ \\
\hline F. equiseti & $15 \pm \underset{\mathrm{a}}{ \pm} 0.7$ & $19 \underset{\mathrm{a}}{ \pm} 0.7$ & $20 \underset{\mathrm{a}}{ \pm} 0.7$ & $26 \underset{a}{a} .5$ & $33 \underset{\mathrm{a}}{3} 0.9$ & - & $17 \underset{\mathrm{a}}{ \pm} 0.3$ & $18 \underset{\mathrm{a}}{ \pm} 0.7$ & $24 \underset{\mathrm{a}}{ \pm} 0.9$ & $31 \underset{\mathrm{a}}{ \pm} 0.5$ & - & - & $16 \underset{\mathrm{a}}{ \pm} 0.7$ & $21 \underset{\mathrm{a}}{ \pm} 0.2$ & $28 \underset{\mathrm{a}}{2} \pm .8$ \\
\hline F. avenaceum & $\begin{array}{l}14 \pm \\
0.6^{\mathrm{ab}}\end{array}$ & $18 \pm 0.1$ & $19 \underset{\mathrm{ab}}{ \pm} 0.3$ & $24 \underset{\mathrm{b}}{ \pm} 0.3$ & $31 \underset{\mathrm{b}}{ \pm} 0.5$ & - & $16 \underset{\mathrm{ab}}{ \pm} 0.1$ & $17 \underset{\mathrm{ab}}{ \pm} 0.6$ & $22 \underset{\mathrm{b}}{ \pm} 0.1$ & $29 \underset{\mathrm{b}}{ \pm} 0.4$ & - & - & $15 \underset{\mathrm{ab}}{ \pm} 0.1$ & $19 \underset{\mathrm{b}}{ \pm} 0.4$ & $26 \underset{\mathrm{b}}{ \pm} 0.4$ \\
\hline \multicolumn{16}{|c|}{ Candida } \\
\hline C. gelbeta & $9 \underset{\mathrm{d}}{ \pm} 0.1$ & $12 \underset{\mathrm{d}}{ \pm} 0.4$ & $15 \pm 0.2$ & $18 \underset{\mathrm{e}}{ \pm 0.5}$ & $25 \pm 0.1$ & - & $10 \underset{c}{ \pm} 0.5$ & $12 \pm 0.1$ & $16 \underset{d}{\mathrm{~d}} 0.5$ & $22 \underset{\mathrm{e}}{ \pm} 0.4$ & - & $8 \underset{\mathrm{d}}{ \pm} 0.1$ & $10 \pm 0.1$ & $14 \underset{\mathrm{d}}{ \pm} 0.8$ & $18 \underset{\mathrm{e}}{ \pm} 0.1$ \\
\hline C. tropicalis & $11_{c}^{ \pm} 0.3$ & $15 \underset{\mathrm{bc}}{ \pm} 0.2$ & $19 \underset{c}{ \pm} 0.0$ & $22 \underset{\mathrm{cd}}{ \pm} 0.1$ & $30 \underset{c}{ \pm} 0.2$ & - & $12 \underset{\mathrm{bc}}{ \pm} 0.1$ & $15 \underset{c}{ \pm} 0.2$ & $20 \underset{\mathrm{bc}}{ \pm} 0.1$ & $27 \underset{c}{ \pm} 0.7$ & - & $10 \underset{\mathrm{bc}}{ \pm} 0.4$ & $13 \underset{\mathrm{cd}}{ \pm} 0.4$ & $18 \underset{\mathrm{bc}}{ \pm} 0.7$ & $23 \underset{c}{ \pm} 0.5$ \\
\hline C. albicans & $10 \underset{\mathrm{cd}}{ \pm} 0.1$ & $13 \underset{c}{ \pm} 0.9$ & $17 \underset{\mathrm{d}}{ \pm} 0.3$ & $21 \underset{\mathrm{d}}{ \pm} 0.2$ & $28 \underset{\mathrm{d}}{\mathrm{d}} 0.8$ & - & $11 \underset{c}{ \pm} 0.2$ & $14 \underset{\mathrm{d}}{ \pm} 0.7$ & $19 \underset{c}{ \pm} 0.2$ & $25 \underset{\mathrm{d}}{\mathrm{d}} 0.4$ & - & $9 \underset{c}{ \pm} 0.1$ & $12 \underset{\mathrm{d}}{\mathrm{d}} 0.5$ & $17 \underset{c}{ \pm} 0.6$ & $21 \underset{\mathrm{d}}{ \pm} 0.3$ \\
\hline R. rubra & $14 \underset{\mathrm{ab}}{ \pm} 0.6$ & $17 \underset{\mathrm{ab}}{ \pm} 0.7$ & $21 \underset{\mathrm{b}}{ \pm} 0.4$ & $25 \underset{\mathrm{b}}{ \pm} 0.4$ & $32 \underset{\mathrm{b}}{ \pm} 0.7$ & $13 \underset{\mathrm{ab}}{ \pm} 0.1$ & $15 \underset{\mathrm{ab}}{ \pm} 0.7$ & $18 \underset{\mathrm{b}}{ \pm} 0.9$ & $22 \underset{\mathrm{ab}}{ \pm} 0.4$ & $29 \frac{ \pm}{b} 0.2$ & - & $13 \underset{\mathrm{ab}}{ \pm} 0.5$ & $16 \underset{\mathrm{b}}{ \pm} 0.2$ & $20 \underset{\mathrm{ab}}{ \pm} 0.1$ & $25 \underset{\mathrm{b}}{ \pm} 0.6$ \\
\hline R. minuta & $13 \frac{ \pm}{\mathrm{b}} 0.4$ & $16 \underset{\mathrm{b}}{ \pm} 0.6$ & $20 \underset{\mathrm{bc}}{ \pm} 0.1$ & $23 \underset{c}{ \pm} 0.9$ & $31 \underset{\mathrm{bc}}{ \pm} 0.1$ & $12 \underset{\mathrm{b}}{ \pm} 0.5$ & $13 \underset{\mathrm{b}}{ \pm} 0.6$ & $16 \underset{c}{ \pm} 0.6$ & $21 \underset{\mathrm{b}}{ \pm} 0.4$ & $28 \underset{\mathrm{bc}}{ \pm} 0.5$ & - & $11 \underset{\mathrm{b}}{ \pm} 0.1$ & $14 \underset{c}{ \pm} 0.7$ & $19 \underset{\mathrm{b}}{ \pm} 0.2$ & $24 \underset{\mathrm{bc}}{ \pm} 0.4$ \\
\hline R.mucilginosa & $15 \pm 0.9$ & $18 \underset{\mathrm{a}}{ \pm} 0.5$ & $23 \underset{\mathrm{a}}{ \pm} 0.9$ & $27 \underset{\mathrm{a}}{ \pm} 0.0$ & $34 \underset{\mathrm{a}}{ \pm} 0.2$ & $14 \underset{\mathrm{a}}{ \pm} 0.4$ & $16 \pm \underset{\mathrm{a}}{\mathrm{a}} 0.9$ & $20 \underset{\mathrm{a}}{ \pm} 0.4$ & $23 \underset{\mathrm{a}}{ \pm} 0.1$ & $31 \underset{\mathrm{a}}{ \pm} 0.1$ & - & $14 \underset{\mathrm{a}}{ \pm} 0.4$ & $18 \underset{\mathrm{a}}{\mathrm{a}} 0.2$ & $21 \underset{\mathrm{a}}{ \pm} 0.7$ & $27 \underset{\mathrm{a}}{ \pm} 0.7$ \\
\hline
\end{tabular}

$\mathrm{ND}$, not detected, All values are expressed as the means \pm SD. Means with different lowercase letters in the same column indicate significant differences at $p \leq 0.05$ by LSD.

Table 6. Minimum inhibitory concentration (MIC), minimum bactericidal concentration (MBC), and minimum fungicidal concentration (MFC) of black, red and white kidney bean protein hydrolysate (BKH, RKH and $\mathrm{WKH})$ obtained after $30 \mathrm{~min}$ Alcalase hydrolysis at $37^{\circ} \mathrm{C}$, against different microbial strains.

\begin{tabular}{|c|c|c|c|c|c|c|}
\hline \multirow{2}{*}{$\begin{array}{l}\text { Microorganisms } \\
\text { Bacteria }\end{array}$} & \multicolumn{2}{|c|}{ BKH } & \multicolumn{2}{|c|}{ RKH } & \multicolumn{2}{|c|}{ WKH } \\
\hline & MIC & MBC & MIC & MBC & MIC & MBC \\
\hline Bacillus cereus & $30^{\mathrm{e}}$ & $55^{\mathrm{e}}$ & $40^{\mathrm{e}}$ & $80^{\mathrm{e}}$ & $65^{\mathrm{e}}$ & $120^{\mathrm{e}}$ \\
\hline listeria monocytogenes & $35^{d}$ & $65^{d}$ & $45^{\mathrm{d}}$ & $85^{\mathrm{d}}$ & $70^{d}$ & $130^{\mathrm{d}}$ \\
\hline Streptococcus pyogenes & $25^{f}$ & $50^{f}$ & $35^{f}$ & $65^{f}$ & $60^{f}$ & $110^{f}$ \\
\hline Escherichia coli & $40^{\mathrm{c}}$ & $75^{c}$ & $65^{c}$ & $125^{\mathrm{c}}$ & $75^{c}$ & $140^{\mathrm{c}}$ \\
\hline Campylobacter jejuni & $45^{\mathrm{a}}$ & $85^{\mathrm{a}}$ & $75^{\mathrm{a}}$ & $145^{\mathrm{a}}$ & $90^{\mathrm{a}}$ & $175^{\mathrm{a}}$ \\
\hline Salmonella typhi & $40^{b}$ & $75^{b}$ & $70^{b}$ & $130^{b}$ & $80^{b}$ & $155^{b}$ \\
\hline Fungi & MIC & MFC & MIC & MFC & MIC & MFC \\
\hline Aspergillus niger & $45^{\mathrm{a}}$ & $90^{\mathrm{a}}$ & $90^{\mathrm{a}}$ & $170^{a}$ & $180^{a}$ & $320^{\mathrm{a}}$ \\
\hline Aspergillus fumigatus & $35^{c}$ & $70^{c}$ & $75^{c}$ & $140^{\mathrm{C}}$ & $140^{\mathrm{c}}$ & $270^{c}$ \\
\hline Aspergillus flavus & $40^{b}$ & $75^{b}$ & $80^{b}$ & $150^{b}$ & $150^{b}$ & $280^{b}$ \\
\hline Penicillium chrysogenum & $30^{d}$ & $55^{d}$ & $70^{d}$ & $130^{d}$ & $135^{\mathrm{d}}$ & $250^{d}$ \\
\hline Fusarium equiseti & $25^{f}$ & $50^{\mathrm{f}}$ & $60^{f}$ & $110^{\mathrm{f}}$ & $110^{\mathrm{f}}$ & $200^{f}$ \\
\hline Fusarium avenaceum & $30^{\mathrm{e}}$ & $55^{\mathrm{e}}$ & $65^{\mathrm{e}}$ & $120^{\mathrm{e}}$ & $120^{\mathrm{e}}$ & $220^{\mathrm{e}}$ \\
\hline \multicolumn{7}{|l|}{ Candida } \\
\hline Candia gelbeta & $45^{\mathrm{a}}$ & $90^{\mathrm{a}}$ & $80^{a}$ & $150^{\mathrm{a}}$ & $90^{a}$ & $170^{\mathrm{a}}$ \\
\hline Candida tropicalis & $35^{c}$ & $70^{c}$ & $65^{c}$ & $120^{\mathrm{c}}$ & $80^{c}$ & $150^{c}$ \\
\hline Candida albicans & $40^{b}$ & $75^{b}$ & $70^{b}$ & $130^{b}$ & $85^{b}$ & $160^{\mathrm{b}}$ \\
\hline Rhodotorula rubra & $25^{\mathrm{e}}$ & $50^{\mathrm{e}}$ & $40^{\mathrm{e}}$ & $70^{\mathrm{e}}$ & $65 \mathrm{e}$ & $120^{\mathrm{e}}$ \\
\hline Rhodotorula minuta & $30^{d}$ & $55^{d}$ & $45^{\mathrm{d}}$ & $80^{d}$ & $70^{d}$ & $130^{\mathrm{d}}$ \\
\hline Rhodotorula mucilginosa & $20^{f}$ & $40^{f}$ & $30^{f}$ & $60^{f}$ & $55^{\mathrm{f}}$ & $100^{\mathrm{f}}$ \\
\hline
\end{tabular}

Means with different lowercase letters in the same column indicate significant differences at $p \leq 0.05$ by LSD.

By comparison, of the values of MIC and MFC against the fungi with MIC and MBC against the studied bacteria (Table 6) refer to higher values in the case of the fungi. This difference may indicate that kidney protein hydrolysates are less effective against fungi than bacteria. The possible mechanisms indicate earlier suits more bacteria than fungi, whose biochemical structure is more sophisticated than the bacteria. 


\subsection{Chicken Meat Preservation with Kidney Bean Protein Hydrolysates}

\subsubsection{Physicochemical Changes during Cold Storage}

Table 7 presents the changes in some physicochemical parameters of raw chicken meat during cold storage for 30 days, i.e., $\mathrm{pH}$, metmyoglobin (\%), TVBN (mg N/100 g), and lipid oxidation inhibition (\%), in response to graded additions of BKH, RKH and WKH. All parameters significantly increased with increasing the storage period from 0 to 10, 20, and 30 days, but lipid oxidation inhibition (\%) significantly decreased. The $\mathrm{pH}$ values, metmyoglobin, and TVBN significantly decreased with the increments of $\mathrm{BKH}, \mathrm{RKH}$, and WKH concentrations $(200,400$, and $800 \mu \mathrm{g} / \mathrm{g})$ in a concentration-dependent manner. The $\mathrm{pH}$ value of the control sample increased from 5.6 to 8.9, i.e., reflecting a $40 \%$ relative increase after 30 days of cold storage. Supplementing meat with protein hydrolysate $(800 \mu \mathrm{g} / \mathrm{g})$ decreased $\mathrm{pH}$ by $25-30 \%$ of the control value after 30 -day cold storage. The increase in the $\mathrm{pH}$ value with storage time (30 days) in the control samples coincided with parallel increases in total volatile basic nitrogen (TVBN), i.e., from $6.5 \mathrm{mg} \mathrm{N} / 100 \mathrm{~g}$ at zero time to $8.35 \mathrm{mg} \mathrm{N} / 100 \mathrm{~g}$ after 30 days of cold storage. This $\mathrm{pH}$ increase is probably a result of the metabolic activities of the contaminating spoilage bacteria, which can hydrolyze the proteins and lipids producing NH3 [86]. Treating the stored meat with the protein hydrolysate significantly reduced this value in a concentration-dependent manner, specially BKH $(800 \mu \mathrm{g} / \mathrm{g})$, which maintained the level of TVBN down to $6.50 \mathrm{mg} \mathrm{N} / 100 \mathrm{~g}$ after 30 days of cold storage. This action is apparently due to the antibacterial activity of the protein hydrolysate previously evidenced. Similar results were observed by Saad, et al. [21], who reported that minced beef supplementation with pepsin kidney bean hydrolysate $(100$, and $200 \mu \mathrm{g} / \mathrm{g})$ reduced the $\mathrm{pH}$ increase by $10 \%$. The level of Met-myoglobin in the control sample increased rapidly with storage reaching $52.5 \%$ after 30 days of cold storage, i.e., exceeding the acceptable level in meat $(40 \%)$. The addition of protein hydrolysates $(800 \mu \mathrm{g} / \mathrm{g})$ to chicken meat significantly slowed down the rate of meat deterioration, keeping the level of metmyoglobin down to $22-28 \%$ after 30 days storage, i.e., achieving relative reductions of about $58-47 \%$ of the control value, respectively. The highest reduction $(58 \%)$ was achieved by BKH $(800 \mu \mathrm{g} / \mathrm{g})$. The increase in metmyoglobin with storage is evidently due to the auto-oxidation of meat protein and the oxidation of myoglobin to met-myoglobin, leading to undesirable meat color [87]. The reduction of this value by hydrolysate addition is probably due to their antioxidant action, previously quantified (Figure 3). Finally, the addition of protein hydrolysates to chicken meat at a high level $(800 \mu \mathrm{g} / \mathrm{g})$ significantly increased the efficiency of inhibiting lipid oxidation by about $59-70 \%$ over the control. The addition of protein hydrolysate to the preserved meat significantly inhibited the unwanted oxidative changes because of antioxidant activity, previously mentioned. Lipid oxidation is the main factor affecting the meat's lifetime during storage. The formation of hydroperoxides and aldehydes are indicators of lipid oxidation [88]. Piñuel, et al. [89] found the addition of phaseolin isolated from red kidney bean to zebrafish inhibited the lipid oxidation by $82 \%$, and Aslam, et al. [90] found that the addition of fish protein hydrolysate to chicken meat breast during storage delayed the lipid oxidation and all unwanted changes.

Table 7. Physicochemical changes in raw chicken meat supplemented with black, red, and white kidney bean protein hydrolysate (BKH, RKH, and WKH) obtained by alcalase after 30 min hydrolysis, at 0-30 days cold storage at $4{ }^{\circ} \mathrm{C}$.

\begin{tabular}{|c|c|c|c|c|c|c|c|c|c|c|c|c|c|c|c|c|c|}
\hline \multirow{3}{*}{ Sample } & \multirow{3}{*}{$\begin{array}{l}\text { Concn } \\
(\mu g / g)\end{array}$} & \multicolumn{16}{|c|}{ Duration of Cold Storage (Days) } \\
\hline & & 0 & 10 & 20 & 30 & 0 & 10 & 20 & 30 & 0 & 10 & 20 & 30 & 0 & 10 & 20 & 30 \\
\hline & & \multicolumn{4}{|c|}{$\mathrm{pH}$} & \multicolumn{4}{|c|}{ TVBN (mg N/100 g Sample) } & \multicolumn{4}{|c|}{ Metmyoglobin (\%) } & \multicolumn{4}{|c|}{ Lipid Oxidation Inhibition (\%) } \\
\hline Cont & 0.0 & $5.60^{\mathrm{a}}$ & $6.57^{\mathrm{a}}$ & $7.50^{\mathrm{a}}$ & $8.90^{\mathrm{a}}$ & $6.50^{\mathrm{a}}$ & $7.20^{\mathrm{a}}$ & $7.80^{\mathrm{a}}$ & $8.35^{\mathrm{a}}$ & $9.00^{\mathrm{a}}$ & $28.00^{a}$ & $42.00^{a}$ & $52.50^{\mathrm{a}}$ & $33^{\mathrm{ab}}$ & $24^{c}$ & $18^{\mathrm{c}}$ & $9^{d}$ \\
\hline \multirow{3}{*}{$\mathrm{BKH}$} & 200 & $5.45^{b}$ & $5.90^{c}$ & $6.45^{c}$ & $7.00^{c}$ & $6.22^{c}$ & $6.50^{c}$ & $6.95^{c}$ & $7.20^{c}$ & $8.99^{\mathrm{a}}$ & $18.00^{c}$ & $21.00^{\mathrm{b}}$ & $30.00^{\mathrm{b}}$ & $33^{\mathrm{ab}}$ & $29^{b}$ & $27^{c}$ & $17^{\mathrm{c}}$ \\
\hline & 400 & $5.31^{b}$ & $5.70^{c}$ & $6.20^{c}$ & $6.82^{d}$ & $6.10^{d}$ & $6.20^{c}$ & $6.45^{c}$ & $6.80^{d}$ & $8.15^{b}$ & $13.90^{\mathrm{d}}$ & $16.00^{\mathrm{c}}$ & $25.00^{c}$ & $33^{a b}$ & $31^{b}$ & $29^{b}$ & $25^{b}$ \\
\hline & 800 & $5.19^{c}$ & $5.66^{c}$ & $5.90^{\mathrm{d}}$ & $6.24^{\mathrm{d}}$ & $5.56^{\mathrm{e}}$ & $5.86^{\mathrm{d}}$ & $6.30^{c}$ & $6.50^{\mathrm{d}}$ & $7.51^{\mathrm{c}}$ & $11.30^{\mathrm{d}}$ & $14.55^{c}$ & $22.60^{c}$ & $34^{\mathrm{a}}$ & $33^{\mathrm{a}}$ & $32^{\mathrm{a}}$ & $30^{\mathrm{a}}$ \\
\hline \multirow{3}{*}{ RKH } & 200 & $5.48^{b}$ & $6.00^{b}$ & $7.00^{b}$ & $7.41^{b}$ & $6.34^{b}$ & $6.80^{b}$ & $7.20^{b}$ & $7.40^{c}$ & $8.8^{a}$ & $20.30^{b}$ & $25.90^{b}$ & $35.00^{b}$ & $33^{\mathrm{ab}}$ & $27^{c}$ & $25^{c}$ & $14^{\mathrm{c}}$ \\
\hline & 400 & $5.34^{b}$ & $5.70^{\mathrm{c}}$ & $6.50^{c}$ & $6.90^{\mathrm{d}}$ & $6.19^{c}$ & $6.40^{\mathrm{c}}$ & $6.90^{c}$ & $7.15^{c}$ & $8.3^{b}$ & $16.10^{c}$ & $23.10^{b}$ & $31.50^{\mathrm{b}}$ & $34^{\mathrm{a}}$ & $30^{b}$ & $28^{\mathrm{b}}$ & $21^{c}$ \\
\hline & 800 & $5.29^{c}$ & $5.50^{c}$ & $6.20^{c}$ & $6.50^{\mathrm{d}}$ & $6.11^{\mathrm{d}}$ & $6.31^{\mathrm{c}}$ & $6.50^{c}$ & $6.80^{\mathrm{d}}$ & $7.9^{\mathrm{c}}$ & $13.30^{\mathrm{d}}$ & $16.80^{c}$ & $27.30^{c}$ & $35^{\mathrm{a}}$ & $32^{\mathrm{ab}}$ & $30^{\mathrm{b}}$ & $28^{\mathrm{b}}$ \\
\hline
\end{tabular}


Table 7. Cont.

\begin{tabular}{|c|c|c|c|c|c|c|c|c|c|c|c|c|c|c|c|c|c|}
\hline \multirow{3}{*}{ Sample } & \multirow{3}{*}{$\begin{array}{l}\text { Concn } \\
(\mu \mathrm{g} / \mathrm{g})\end{array}$} & \multicolumn{16}{|c|}{ Duration of Cold Storage (Days) } \\
\hline & & 0 & 10 & 20 & 30 & 0 & 10 & 20 & 30 & 0 & 10 & 20 & 30 & 0 & 10 & 20 & 30 \\
\hline & & \multicolumn{4}{|c|}{$\mathrm{pH}$} & \multicolumn{4}{|c|}{ TVBN (mg N/100 g Sample) } & \multicolumn{4}{|c|}{ Metmyoglobin (\%) } & \multicolumn{4}{|c|}{ Lipid Oxidation Inhibition (\%) } \\
\hline \multirow{3}{*}{ WKH } & 200 & $\underset{\mathrm{ab}}{5.56}$ & $6.20^{\mathrm{b}}$ & $7.10^{\mathrm{b}}$ & $7.65^{b}$ & $\underset{\mathrm{ab}}{6.40}$ & $\begin{array}{c}7.00 \\
\mathrm{ab}\end{array}$ & $7.40^{\mathrm{b}}$ & $7.90^{\mathrm{b}}$ & $8.90^{\mathrm{a}}$ & $22.40^{\mathrm{b}}$ & $28.00^{b}$ & $37.80^{\mathrm{b}}$ & $35^{\mathrm{a}}$ & $25^{c}$ & $23^{c}$ & $11^{\mathrm{d}}$ \\
\hline & 400 & $5.45^{\mathrm{b}}$ & $6.00^{\mathrm{b}}$ & $6.80^{\mathrm{c}}$ & $7.10^{\mathrm{c}}$ & $6.35^{\mathrm{b}}$ & $6.70^{\mathrm{b}}$ & $7.00^{\mathrm{b}}$ & $7.20^{\mathrm{c}}$ & $8.5^{\mathrm{ab}}$ & $17.50^{\mathrm{c}}$ & $24.50^{\mathrm{b}}$ & $31.50^{\mathrm{b}}$ & $34^{\mathrm{a}}$ & $27^{\mathrm{c}}$ & $25^{c}$ & $19^{c}$ \\
\hline & 800 & $5.33^{b}$ & $5.80^{c}$ & $6.20^{c}$ & $6.78^{\mathrm{d}}$ & $6.21^{c}$ & $6.45^{\mathrm{b}}$ & $6.80^{c}$ & $7.00^{c}$ & $8.2^{b}$ & $14.70^{\mathrm{d}}$ & $20.30^{c}$ & $28.00^{c}$ & $35^{\mathrm{a}}$ & $29^{b}$ & $28^{\mathrm{b}}$ & $22^{\mathrm{c}}$ \\
\hline
\end{tabular}

TVBN: Total volatile basic nitrogen. Means with different lowercase letters in the same column indicate significant differences at $p \leq 0.05$ by LSD.

3.2.2. Fluctuation in Color Parameters and Sensorial Traits of Raw Chicken Meat during 30 Days of Cold Storage

Figure 5 presents and predict the changes in the color parameters in chicken meat samples supplemented or un-supplemented with kidney bean protein hydrolysates after 30 days of cold storage. The whiteness indicator $\left(L^{*}\right)$ of chicken meat significantly increased with WKH $(800 \mu \mathrm{g} / \mathrm{g})$ from 60.15 in control sample to 61.90, with a relative increase of $12 \%$ over control. However, RKH supplementation $(800 \mu \mathrm{g} / \mathrm{g})$ increased the redness $\left(a^{*}\right)$ of chicken meat by $10 \%$ over the control, and BKH addition $(800 \mu \mathrm{g} / \mathrm{g})$ increased the blueness $\left(b^{*}\right)$ of meat by $12 \%$ over the control. Meat whiteness is expected to increase with increasing WKH concentration, however decreased with increasing BKH concentration (Figure $5 \mathrm{~A}-\mathrm{C})$. The results were confirmed by total color change $(\Delta \mathrm{E})$ in Figure 6 . The highest total color change showed in meat sample supplemented with WKH (400 $\mu \mathrm{g} / \mathrm{g})$, i.e., 2.4 with relative increase $25 \%$ about control. However the lowest value was found in samples supplemented with BKH $(200 \mu \mathrm{g} / \mathrm{g})$, i.e., 0.5. Generally, the color parameters faded after 30 days of storage, but supplementation with BKH, RKH and WKH significantly maintained about $75 \%$ of color attributes. Ab Aziz, et al. [91] found that all color parameters of chicken meat preserved at different temperature degrees decreased with the storage period. No available studies cast light on the changes in color parameters and sensorial traits of chicken meat samples supplemented with kidney bean protein hydrolysates. The addition of $(\mathrm{BKH}, \mathrm{RKH}$, and $\mathrm{WKH})$ significantly maintained the meat quality, where BKH-supplemented chicken meat samples recorded the highest scores in tenderness and juiciness, i.e., 8.5, and 8.7 at zero-time storage (Table 8 and Figure 7), as it had the highest scores in water holding capacity in its original status. BKH also improved the taste and flavor of cooked chicken meat. A lower magnitude of meat quality improvement was recorded with RKH and WKH supplementation. Generally, all meat quality decreased after 30-day storage, but supplementation with the studied hydrolysates significantly reduced the deterioration rate by about $50-65 \%$ and reduction may be increased by increasing $\mathrm{BKH}$ concentration (Table 8 and Figure 7). It was observed that the sensory attributes of nuggets meat samples were significant during cold storage. However nuggets incorporated with GPP and GSCP had better shelf life and are highly acceptable than control [92].

\subsubsection{Microbial Changes in Chicken Meat during 30 Days Cold Storage}

Table 9 and Figure 8 showed a significant $p \leq 0.05$ increase in bacterial load during 30 days of cold storage. Supplementing chicken meat with a high concentration $(800 \mu \mathrm{g} / \mathrm{g})$ of $\mathrm{BKH}, \mathrm{RKH}$, and WKH significantly $p \leq 0.05$ reduced the total bacterial count (mesophilic) and psychrophilic bacterial count by $35-45 \%$ over control after 30 days of cold storage. The potential antibacterial activity of the kidney bean protein hydrolysates could contribute to maintaining meat quality for about 20-30 days under refrigeration conditions. Saad, et al. [21] used pepsin kidney bean protein hydrolysate in maintaining minced beef quality by reducing microbial load by $22 \%$. The acceptable total bacterial count in raw buffalo meat is less than $<1 \times 10^{6} \mathrm{CFU} / \mathrm{g}$, based on Egyptian Standards (E.S.) No. 4334/2004 [93] following the International Commission on Microbiological Specification (ICMS, 1982). So, the BKH $(800 \mu \mathrm{g} / \mathrm{g})$-enriched chicken may valid for human consumption after about 28-29 days of cold storage. While, chicken meat enriched with 
RKH $(800 \mu \mathrm{g} / \mathrm{g})$ is acceptable for consumption after 20 days of cold storage and WKH has the least shelf life, less than 20 days, and more than ten days of cold storage.

A

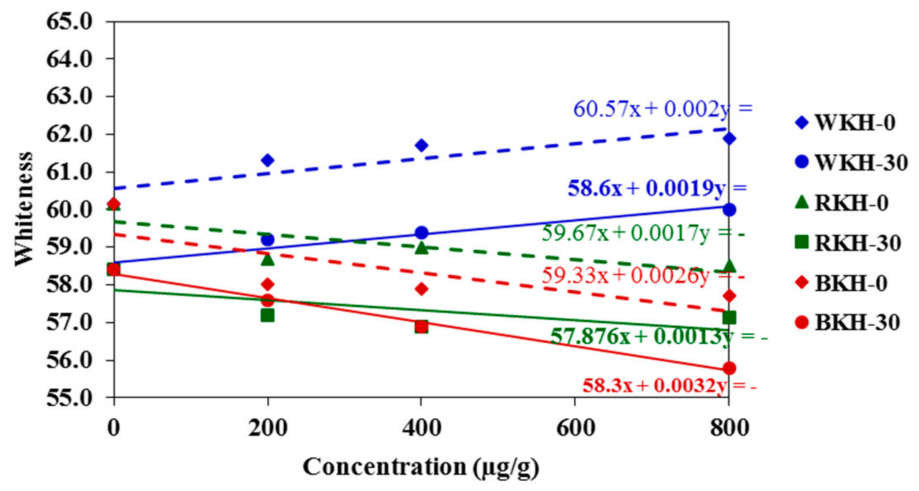

B
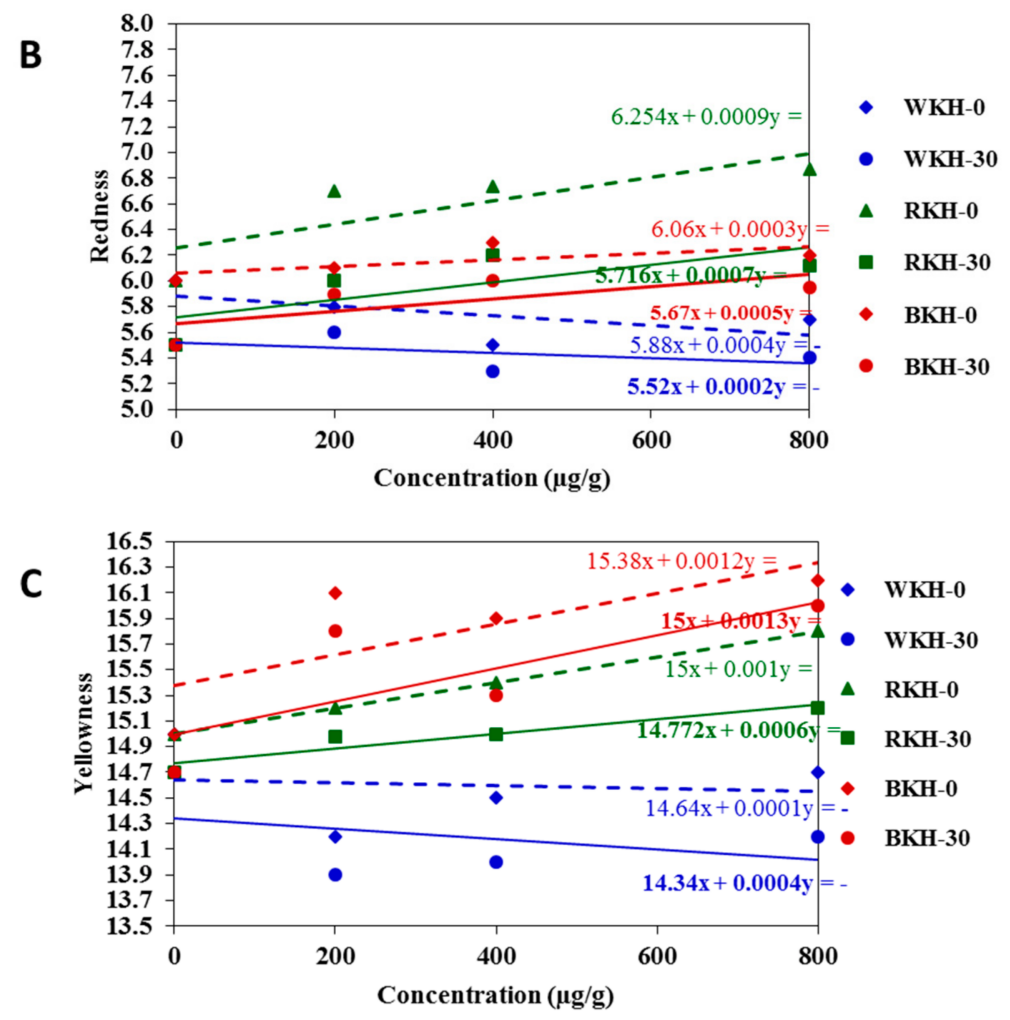

Figure 5. The changes in color parameters (A) Whiteness values, (B) Redness values, (C) yellowness values of supplemented meat with $\mathrm{WKH}, \mathrm{RKH}$, and BKH with increasing concentrations or storage period expressed by trendline regression curves for results prediction. 


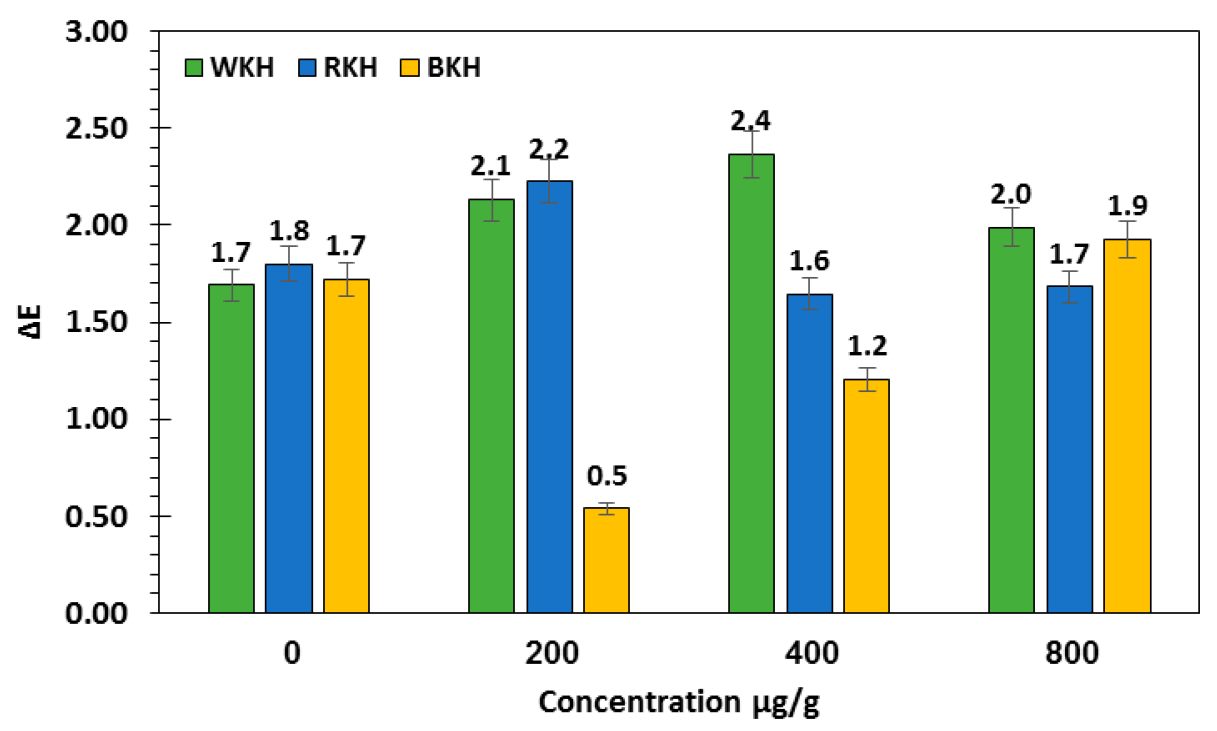

Figure 6. Total color change $(\Delta \mathrm{E})$ of meat samples supplemented with kidney bean hydrolysates during storage period.

Table 8. Sensory properties of cooked chicken meat supplemented with black, red, and white kidney bean protein hydrolysate (BKH, RKH, and $\mathrm{WKH})$ obtained by $30 \mathrm{~min}$ Alcalase hydrolysis, at 0 and 30 days cold storage at $4{ }^{\circ} \mathrm{C}$.

\begin{tabular}{|c|c|c|c|c|c|c|c|c|c|c|c|}
\hline \multirow{3}{*}{ Sample } & \multirow{3}{*}{$\begin{array}{l}\text { Concn } \\
(\mu \mathrm{g} / \mathrm{g})\end{array}$} & \multicolumn{10}{|c|}{ Storage (Day) } \\
\hline & & 0 & 30 & 0 & 30 & 0 & 30 & 0 & 30 & 0 & 30 \\
\hline & & \multicolumn{2}{|c|}{ Tenderness } & \multicolumn{2}{|c|}{ Juiciness } & \multicolumn{2}{|c|}{ Taste } & \multicolumn{2}{|c|}{ Aroma } & \multicolumn{2}{|c|}{ Overall Acceptability } \\
\hline Cont. & 0 & $7.9 \pm 0.1$ & $4.2 \pm 0.2$ & $8.4 \underset{\mathrm{a}}{ \pm} 0.2$ & $3.3 \pm 0.2^{b}$ & $8.5 \pm 0.1$ & $3.0 \pm 0.2^{b}$ & $7.4 \pm 0.6$ & $2.6 \pm 0.5^{b}$ & $8.0 \pm \frac{ \pm}{a} 0.1$ & $3.3 \pm 0.2^{b}$ \\
\hline \multirow{3}{*}{ BKH } & 200 & $8.6 \underset{\mathrm{a}}{ \pm} 0.3$ & $5.0 \underset{b}{ \pm} 0.3$ & $8.4 \underset{\mathrm{a}}{ \pm} 0.4$ & $4.3 \pm 0.6^{b}$ & $8.5 \pm 0.1$ & $3.5 \pm 0.4^{b}$ & $7.7 \pm 0.7$ & $3.3 \pm 0.3^{b}$ & $8.3 \underset{\mathrm{a}}{ \pm} 0.2$ & $4.0 \pm 0.7^{b}$ \\
\hline & 400 & $8.1 \underset{\mathrm{a}}{ \pm} 0.2$ & $5.1 \underset{\mathrm{b}}{ \pm} 0.4$ & $8.6 \underset{\mathrm{a}}{ \pm} 0.3$ & $4.7 \pm 0.7^{b}$ & $8.7 \underset{\mathrm{a}}{ \pm} 0.3$ & $3.7 \pm 0.8^{b}$ & $7.4 \underset{\mathrm{a}}{ \pm} 0.2$ & $3.7 \pm 0.6^{b}$ & $8.2 \pm 0.1$ & $4.3 \pm 0.1^{b}$ \\
\hline & 800 & $8.5 \underset{\mathrm{a}}{ \pm} 0.4$ & $5.3 \underset{\mathrm{b}}{ \pm} 0.5$ & $8.7 \underset{\mathrm{a}}{ \pm} 0.3$ & $4.9 \pm 0.8^{b}$ & $8.7 \underset{\mathrm{a}}{ \pm} 0.3$ & $3.9 \pm 0.6^{b}$ & $7.5 \underset{\mathrm{a}}{ \pm} 0.5$ & $3.7 \pm 0.5^{b}$ & $8.4 \underset{\mathrm{a}}{ \pm} 0.6$ & $4.5 \pm 0.3^{b}$ \\
\hline \multirow{3}{*}{ RKH } & 200 & $8.1 \pm 0.5$ & $4.3 \pm 0.3$ & $8.6 \pm 0.2$ & $4.4 \pm 0.4^{b}$ & $8.5 \pm 0.2$ & $3.3 \pm 0.3^{b}$ & $7.2 \pm 0.3$ & $2.7 \pm 0.5^{b}$ & $8.1 \pm 0.6$ & $3.7 \pm 0.5^{b}$ \\
\hline & 400 & $8.3 \pm 0.2$ & $4.6 \underset{\mathrm{b}}{ \pm} 0.1$ & $8.5 \pm 0.2$ & $4.3 \pm 0.3^{b}$ & $8.6 \pm \frac{\mathrm{a}}{\mathrm{a}} 0.3$ & $3.4 \pm 0.1^{b}$ & $7.5 \pm 0.4$ & $2.9 \pm 0.4^{b}$ & $8.2 \pm 0.7$ & $3.8 \pm 0.9^{b}$ \\
\hline & 800 & $8.4 \underset{\mathrm{a}}{ \pm} 0.2$ & $4.7 \underset{\mathrm{b}}{ \pm} 0.2$ & $8.5 \underset{\mathrm{a}}{ \pm} 0.3$ & $4.1 \pm 0.5^{b}$ & $8.7 \underset{\mathrm{a}}{ \pm} 0.2$ & $3.4 \pm 0.3^{b}$ & $7.9 \pm 0.6$ & $3.0 \pm 0.2^{b}$ & $8.4 \underset{\mathrm{a}}{ \pm} 0.2$ & $3.8 \pm 0.3^{b}$ \\
\hline \multirow{3}{*}{ WKH } & 200 & $8.0 \pm 0.2$ & $4.6 \underset{\mathrm{b}}{ \pm} 0.3$ & $8.5 \underset{\mathrm{a}}{ \pm} 0.3$ & $3.4 \pm 0.5^{b}$ & $8.6 \pm 0.2$ & $3.1 \pm 0.1^{b}$ & $7.0 \pm 0.5$ & $2.9 \pm 0.2^{b}$ & $8.0 \pm 0.1$ & $3.5 \pm 0.6^{b}$ \\
\hline & 400 & $8.2 \pm 0.3$ & $4.9 \underset{\mathrm{b}}{ \pm} 0.1$ & $8.5 \pm 0.2$ & $3.7 \pm 0.4^{b}$ & $8.5 \pm 0.1$ & $3.2 \pm 0.2^{b}$ & $7.4 \underset{\mathrm{a}}{ \pm} 0.7$ & $3.0 \pm 0.4^{b}$ & $8.2 \pm 0.2$ & $3.7 \pm 0.4^{b}$ \\
\hline & 800 & $8.2 \pm 0.1$ & $4.7 \underset{\mathrm{b}}{ \pm} 0.2$ & $8.6 \pm 0.1$ & $3.9 \pm 0.2^{b}$ & $8.6 \pm \frac{\mathrm{a}}{ \pm} 0.1$ & $3.3 \pm 0.1^{b}$ & $7.6 \pm \frac{\mathrm{a}}{ \pm} 0.6$ & $3.2 \pm 0.3^{b}$ & $8.2 \pm 0.4$ & $3.7 \pm 0.8^{b}$ \\
\hline
\end{tabular}

Cont.: control. All values are expressed as the means \pm SD. Means with different lowercase letters in the same column indicate significant differences at $p \leq 0.05$ by LSD. 
A
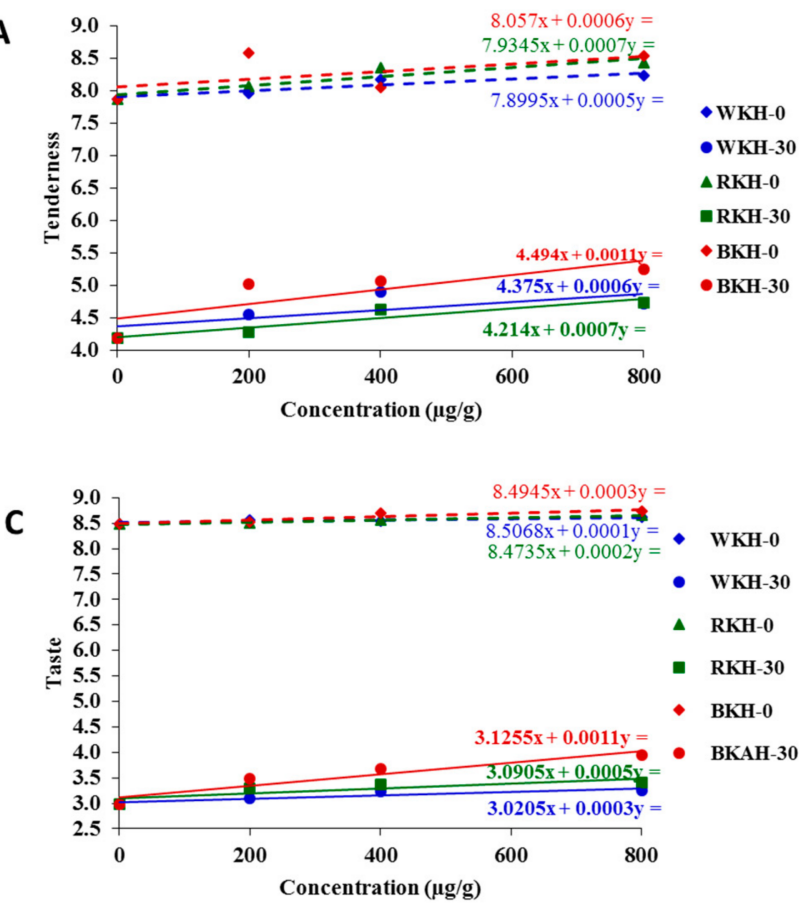

B

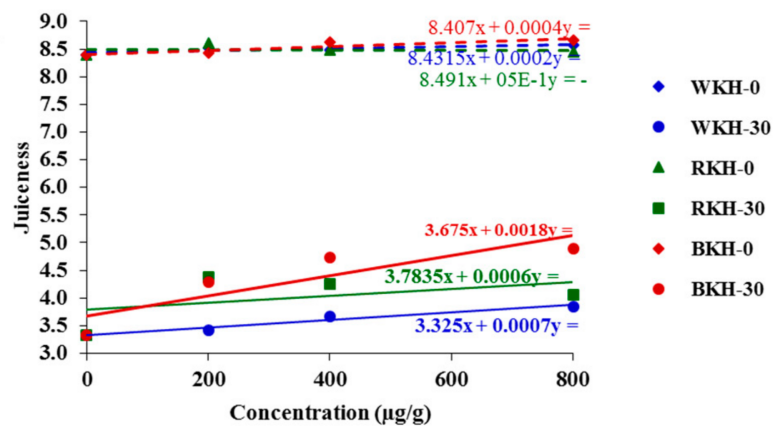

D

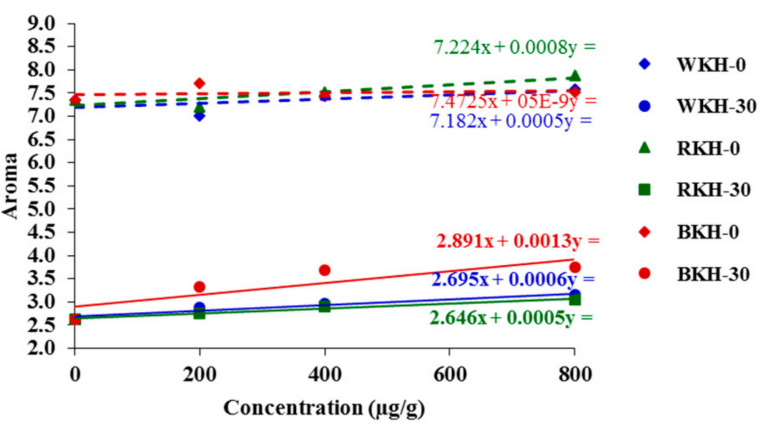

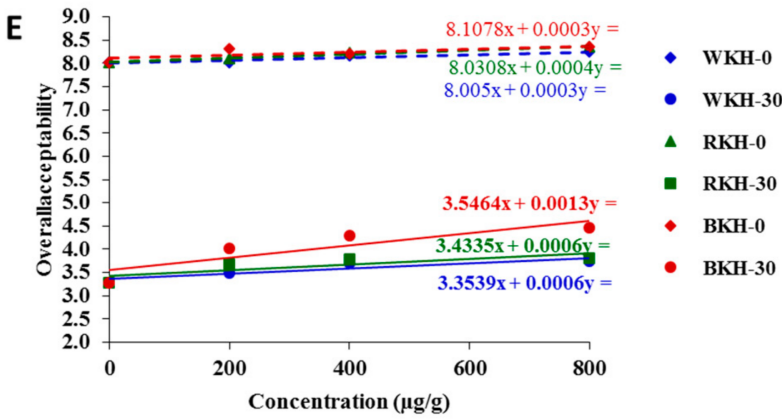

Figure 7. Expected changes in sensory properties; (A) Tenderness, (B) Juiciness, (C) Taste, (D) Aroma, (E) allover acceptability of cooked chicken meat supplemented with $\mathrm{BKH}, \mathrm{RKH}$, and $\mathrm{WKH}$ with increasing concentration or storage period expressed by trendline regression curves for results prediction.

Table 9. Total bacterial count (TBC) and psychrophilic bacterial count (PBC) of raw chicken meat, at 0 and 30 days cold storage at $4{ }^{\circ} \mathrm{C}$, as supplemented with black, red, and white kidney bean protein hydrolysate $(\mathrm{BKH}, \mathrm{RKH}$, and $\mathrm{WKH})$ obtained by 30 min Alcalase hydrolysis.

\begin{tabular}{|c|c|c|c|c|c|c|c|c|c|}
\hline \multirow{2}{*}{ Sample } & \multirow{2}{*}{$\begin{array}{l}\text { Concn } \\
(\mu \mathrm{g} / \mathrm{g})\end{array}$} & \multicolumn{8}{|c|}{ Storage (Day) } \\
\hline & & 0 & 10 & 20 & 30 & 0 & 10 & 20 & 30 \\
\hline & & \multicolumn{4}{|c|}{ Total Bacterial Count (Log CFU/g) } & \multicolumn{4}{|c|}{ Psychrophilic Bacterial Count (Log CFU/g) } \\
\hline \multirow{5}{*}{ ВКH } & 0 & $3.50 \pm 0.17^{a}$ & $5.10 \pm 0.19^{a}$ & $7.9 \pm 0.22^{a}$ & $10.2 \pm 0.14^{\mathrm{a}}$ & $2.80 \pm 0.17^{\mathrm{a}}$ & $4.50 \pm 0.23^{\mathrm{ab}}$ & $7.50 \pm 0.18^{a}$ & $9.20 \pm 0.12^{\mathrm{a}}$ \\
\hline & 200 & $3.31 \pm 0.15^{b}$ & $4.30 \pm 0.21^{b}$ & $6.0 \pm 0.24^{\mathrm{c}}$ & $8.8 \pm 0.17^{\mathrm{b}}$ & $2.66 \pm 0.19^{b}$ & $3.90 \pm 0.25^{c}$ & $6.20 \pm 0.19^{b}$ & $8.50 \pm 0.19^{a t}$ \\
\hline & 400 & $3.25 \pm 0.15^{b}$ & $4.00 \pm 0.12^{b}$ & $5.7 \pm 0.21^{\mathrm{d}}$ & $7.7 \pm 0.14^{c}$ & $2.41 \pm 0.22^{c}$ & $3.50 \pm 0.31^{c}$ & $5.90 \pm 0.21^{c}$ & $7.40 \pm 0.15^{b}$ \\
\hline & 800 & $3.18 \pm 0.11^{b}$ & $3.80 \pm 0.15^{c}$ & $5.0 \pm 0.28^{d}$ & $6.2 \pm 0.22^{\mathrm{d}}$ & $2.33 \pm 0.31^{c}$ & $3.10 \pm 0.33^{c}$ & $4.90 \pm 0.39^{\mathrm{d}}$ & $6.00 \pm 0.17^{c}$ \\
\hline & 0 & $3.60 \pm 0.21^{a}$ & $5.30 \pm 0.18^{a}$ & $8.2 \pm 0.31^{\mathrm{a}}$ & $9.8 \pm 0.21^{\mathrm{a}}$ & $2.75 \pm 0.18^{a}$ & $4.30 \pm 0.25^{b}$ & $6.90 \pm 0.22^{\mathrm{ab}}$ & $8.40 \pm 0.32^{a}$ \\
\hline \multirow{3}{*}{ RKH } & 200 & $3.33 \pm 0.14^{b}$ & $4.60 \pm 0.13^{b}$ & $7.1 \pm 0.25^{b}$ & $8.1 \pm 0.23^{b}$ & $2.61 \pm 0.21^{b}$ & $4.00 \pm 0.27^{b}$ & $6.10 \pm 0.31^{b}$ & $7.90 \pm 0.35^{b}$ \\
\hline & 400 & $3.29 \pm 0.15^{b}$ & $4.40 \pm 0.14^{b}$ & $6.3 \pm 0.21^{c}$ & $7.5 \pm 0.33^{c}$ & $2.55 \pm 0.16^{b}$ & $3.80 \pm 0.31^{\mathrm{c}}$ & $5.80 \pm 0.18^{c}$ & $7.10 \pm 0.18^{b}$ \\
\hline & 800 & $3.21 \pm 0.13^{b}$ & $4.10 \pm 0.18^{b}$ & $5.8 \pm 0.28^{\mathrm{d}}$ & $7.0 \pm 0.11^{\mathrm{c}}$ & $2.45 \pm 0.18^{c}$ & $3.50 \pm 0.21^{c}$ & $5.30 \pm 0.23^{c}$ & $6.50 \pm 0.22$ \\
\hline \multirow{4}{*}{ WKH } & 0 & $3.50 \pm 0.15^{\mathrm{a}}$ & $5.20 \pm 0.14^{\mathrm{a}}$ & $8.4 \pm 0.21^{a}$ & $10.0 \pm 0.11^{\mathrm{a}}$ & $2.80 \pm 0.12^{\mathrm{a}}$ & $4.70 \pm 0.22^{a}$ & $7.10 \pm 0.12^{\mathrm{a}}$ & $8.90 \pm 0.21$ \\
\hline & 200 & $3.40 \pm 0.18^{b}$ & $4.90 \pm 0.12^{\mathrm{ab}}$ & $7.3 \pm 0.25^{b}$ & $8.5 \pm 0.12^{b}$ & $2.79 \pm 0.15^{\mathrm{a}}$ & $4.40 \pm 0.24^{\mathrm{ab}}$ & $6.80 \pm 0.15^{\mathrm{ab}}$ & $7.40 \pm 0.32^{b}$ \\
\hline & 400 & $3.30 \pm 0.17^{b}$ & $4.70 \pm 0.15^{b}$ & $6.8 \pm 0.27^{c}$ & $7.4 \pm 0.15^{\mathrm{c}}$ & $2.62 \pm 0.14^{b}$ & $4.20 \pm 0.27^{b}$ & $6.10 \pm 0.19^{b}$ & $7.00 \pm 0.28^{b}$ \\
\hline & 800 & $3.20 \pm 0.16^{b}$ & $4.50 \pm 0.14^{b}$ & $6.5 \pm 0.23^{c}$ & $7.0 \pm 0.19^{c}$ & $2.59 \pm 0.16^{b}$ & $4.00 \pm 0.23^{b}$ & $5.80 \pm 0.21^{c}$ & $6.70 \pm 0.22^{c}$ \\
\hline
\end{tabular}

All values are expressed as the means \pm SD. Means with different lowercase letters in the same column indicate significant differences at $p \leq 0.05$ by LSD. 


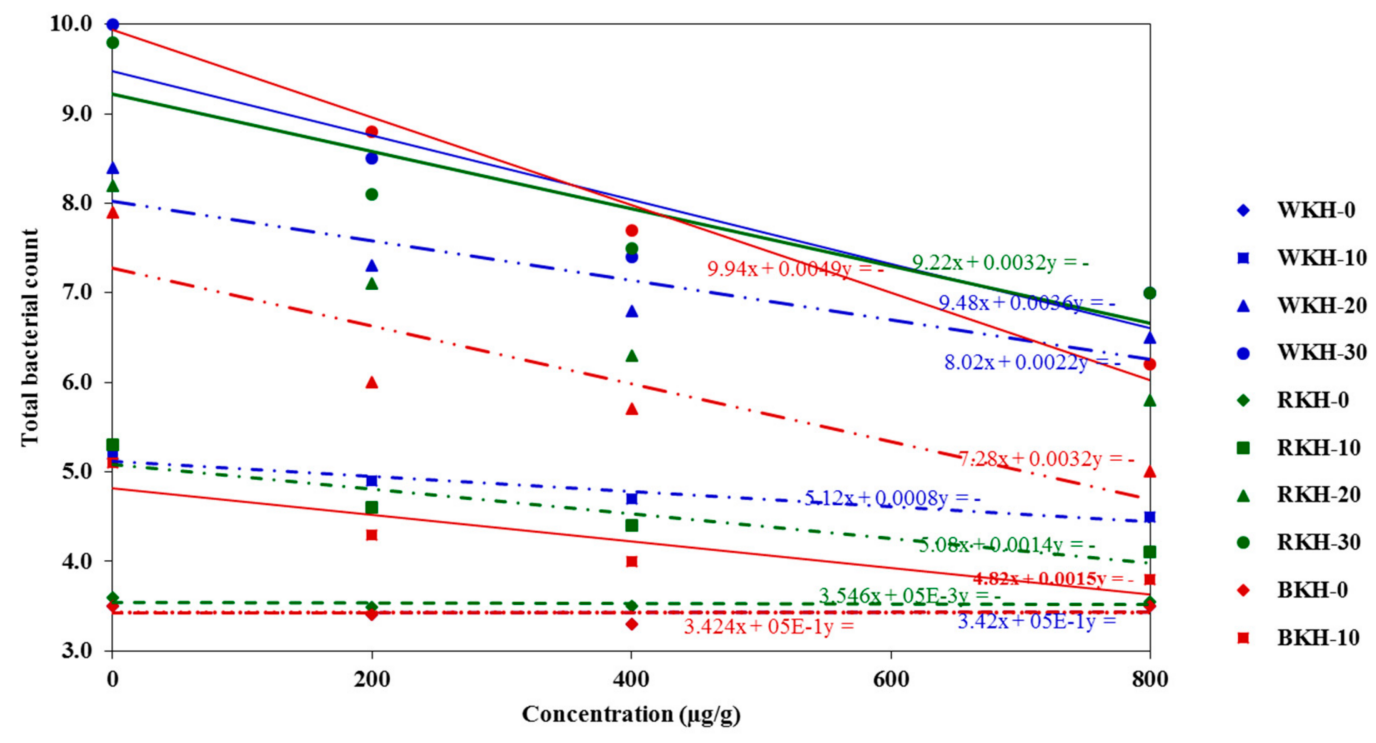

Figure 8. The bacterial load in chicken meat supplemented with $\mathrm{BKH}, \mathrm{RKH}$, and WKH during storage period expressed by trendline regression curves for results prediction.

\section{Conclusions}

Legumes are valuable sources of bioactive peptides that can be used in various ways, including antimicrobial, antithrombotic, antioxidant and antihypertensive. Bioactive peptides can be easily and specifically generated by enzyme hydrolysis and microbial fermentation. The black, red, and white seed proteins can be transformed into valuable bioactive hydrolysate by a short time $(30 \mathrm{~min})$ Alcalase action. The hydrolysate products from the three protein sources also comprised adequate levels of total polyphenols, contributing to their global antioxidant and antimicrobial activities. Consequently, all prepared hydrolysates exhibited excellent antioxidant activities, particularly BKH showing the highest performance. The different hydrolysates (BKH, RKH, and WKH) manifested multiple functional properties like water and oil absorption capacity, emulsifying and foaming properties, especially around $\mathrm{pH} 4$ and 5, which indicate their potential applications in low $\mathrm{pH}$ foods. $\mathrm{BKH}$ is a good candidate for meat preservation based on its capability to counteract lipid, protein and myoglobin oxidation and diminish bacterial and fungal contamination during cold storage. It can extend the cold shelf-life of the stored chicken meat up to 28-29 days while maintaining the sensorial properties to acceptable levels. Generally, the three products can be used in food systems as potential antioxidants and effective antibacterial in the following order of preference $\mathrm{BKH}>\mathrm{RKH}>\mathrm{WKH}$.

Author Contributions: Conceptualization, A.M.S., M.Z.S., A.I.A. and M.T.E.-S. Data curation, S.A.A., N.A.R. Investigation, A.M.S. and M.T.E.-S., S.M.A., M.M.S. Materials and methodology, A.M.S. and M.T.E.-S., S.M.A. Resources, A.M.S. and M.T.E.-S. Formal analysis, A.M.S., M.M.S. Writing-original draft, A.M.S. and M.T.E.-S. Writing-review and editing, M.Z.S., A.M.S. and M.T.E.-S. Funding, S.M.A., M.M.S. All authors have read and agreed to the published version of the manuscript.

Funding: The current work was funded by Taif University, Saudi Arabia, for financial support through its Researchers Supporting Project (TURSP-2020-105).

Institutional Review Board Statement: Not applicable.

Informed Consent Statement: Not applicable.

Data Availability Statement: Not applicable.

Conflicts of Interest: The authors declare no conflict of interest.

Sample Availability: Samples of the compounds are not available from the authors. 


\section{References}

1. Fratamico, P.M.; Bhunia, A.K.; Smith, J.L. Foodborne Pathogens: Microbiology and Molecular Biology; CRC Press LLC: Boca Raton, FL, USA, 2005.

2. CDC. Available online: https:/ / www.cdc.gov/foodsafety/foodborne-germs.html (accessed on 27 July 2021).

3. Anyasi, T.; Jideani, A.I.; Mchau, G.R. Effects of organic acid pretreatment on microstructure, functional and thermal properties of unripe banana flour. J. Food Meas. Charact. 2016, 11, 99-110. [CrossRef]

4. Seabra, R.M.; Andrade, P.B.; Valentao, P.; Fernandes, E.; Carvalho, F.; Bastos, M. Anti-oxidant compounds extracted from several plant materials. In Biomaterials from Aquatic and Terrestrial Organisms; CRC Press: Raton, FL, USA, 2006; pp. 115-174.

5. $\quad$ El-Hack, M.E.A.; El-Saadony, M.T.; Shafi, M.E.; Zabermawi, N.M.; Arif, M.; Batiha, G.E.; Khafaga, A.F.; El-Hakim, Y.M.A.; Al-Sagheer, A.A. Antimicrobial and antioxidant properties of chitosan and its derivatives and their applications: A review. Int. J. Biol. Macromol. 2020, 164, 2726-2744. [CrossRef]

6. Abdelnour, S.A.; Swelum, A.A.; Salama, A.; Al-Ghadi, M.Q.; Qattan, S.Y.A.; El-Hack, M.E.A.; Khafaga, A.F.; Alhimaidi, A.R.; Almutairi, B.O.; Ammari, A.A.; et al. The beneficial impacts of dietary phycocyanin supplementation on growing rabbits under high ambient temperature. Ital. J. Anim. Sci. 2020, 19, 1046-1056. [CrossRef]

7. Ashour, E.; El-Hack, M.; Shafi, M.; Alghamdi, W.; Taha, A.; Swelum, A.; Tufarelli, V.; Mulla, Z.; El-Ghareeb, W.; El-Saadony, M. Impacts of Green Coffee Powder Supplementation on Growth Performance, Carcass Characteristics, Blood Indices, Meat Quality and Gut Microbial Load in Broilers. Agriculture 2020, 10, 457. [CrossRef]

8. El-Saadony, M.T.; Sitohy, M.Z.; Ramadan, M.F.; Saad, A.M. Green nanotechnology for preserving and enriching yogurt with bio-logically available iron (II). Innov. Food Sci. Emerg. Technol. 2021, 69, 102645. [CrossRef]

9. Osman, A.O.; Mahgoub, S.A.; Sitohy, M.Z. Preservative action of $11 S$ (glycinin) and 7S ( $\beta$-conglycinin) soy globulin on bovine raw milk stored either at 4 or $25^{\circ} \mathrm{C}$. J. Dairy Res. 2013, 80, 174-183. [CrossRef] [PubMed]

10. Sitohy, M.Z.; Osman, A.O. Enhancing Milk Preservation with Esterified Legume Proteins. Probiotics Antimicrob. Proteins 2011, 3 , 48-56. [CrossRef] [PubMed]

11. Sitohy, M.; Mahgoub, S.; Osman, A. Controlling psychrotrophic bacteria in raw buffalo milk preserved at $40 \mathrm{C}$ with esterified legume proteins. LWT- Food Sci. Technol. 2011, 44, 1697-1702. [CrossRef]

12. Mahgoub, S.; Osman, A.; Sitohy, M. Inhibition of Growth of Pathogenic Bacteria in Raw Milk by Legume Protein Esters. J. Food Prot. 2011, 74, 1475-1481. [CrossRef]

13. Mahgoub, S.A.; Sitohy, M.Z.; Osman, A.O. Counteracting Recontamination of Pasteurized Milk by Methylated Soybean Protein. Food Bioprocess. Technol. 2011, 6, 101-109. [CrossRef]

14. Osman, A.; Mahgoub, S.; El-Masry, R.; Al-Gaby, A.; Sitohy, M. Extending the Technological Validity of Raw Buffalo Milk at Room Temperature by Esterified Legume Proteins. J. Food Process. Preserv. 2012, 38, 223-231. [CrossRef]

15. El-Saadony, M.T.; Khalil, O.S.F.; Osman, A.; Alshilawi, M.S.; Taha, A.E.; Aboelenin, S.M.; Shukry, M.; Saad, A.M. Bioactive peptides supplemented raw buffalo milk: Biological activity, shelf life and quality properties during cold preservation. Saudi J. Biol. Sci. 2021. [CrossRef]

16. Osman, A.; Goda, H.A.; Sitohy, M. Storage stability of minced beef supplemented with chickpea legumin at $4 \mathrm{C}$ as a potential sub-stitute for nisin. LWT- Food Sci. Technol. 2018, 93, 434-441. [CrossRef]

17. Osman, A.; Abdel-Shafi, S.; Al-Mohammadi, A.-R.; Kamal, N.; Enan, G.; Sitohy, M. Catfish glycoprotein, a highly powerful safe preservative of minced beef stored at $4 \mathrm{C}$ for 15 Days. Foods 2020, 9, 1115. [CrossRef]

18. El-Saadony, M.T.; El-Hack, M.E.A.; Swelum, A.A.; Al-Sultan, S.I.; El-Ghareeb, W.R.; Hussein, E.O.S.; Ba-Awadh, H.A.; Akl, B.A.; Nader, M.M. Enhancing quality and safety of raw buffalo meat using the bioactive peptides of pea and red kidney bean under refrigeration conditions. Ital. J. Anim. Sci. 2021, 20, 762-776. [CrossRef]

19. Abdel-Hamid, M.; Osman, A.; El-Hadary, A.; Romeih, E.; Sitohy, M.; Li, L. Hepatoprotective action of papain-hydrolyzed buffalo milk protein on carbon tetrachloride oxidative stressed albino rats. J. Dairy Sci. 2020, 103, 1884-1893. [CrossRef] [PubMed]

20. Al-Mohammadi, A.-R.; Osman, A.; Enan, G.; Abdel-Shafi, S.; El-Nemer, M.; Sitohy, M.; Taha, M. Powerful Antibacterial Peptides from Egg Albumin Hydrolysates. Antibiotics 2020, 9, 901. [CrossRef] [PubMed]

21. Saad, A.M.; Osman, A.O.M.; Mohamed, A.S.; Ramadan, M.F. Enzymatic hydrolysis of Phaseolus vulgaris protein isolate: Characterization of hydrolysates and effect on the quality of minced beef during cold storage. Int. J. Pept. Res. Ther. 2020, 26, 567-577. [CrossRef]

22. Liu, D.; Chen, X.; Huang, J.; Huang, M.; Zhou, G. Generation of bioactive peptides from duck meat during post-mortem aging. Food Chem. 2017, 237, 408-415. [CrossRef] [PubMed]

23. Lafarga, T.; Hayes, M. Bioactive peptides from meat muscle and by-products: Generation, functionality and application as functional ingredients. Meat Sci. 2014, 98, 227-239. [CrossRef]

24. Escudero, E.; Mora, L.; Fraser, P.D.; Aristoy, M.-C.; Toldrá, F. Identification of novel antioxidant peptides generated in Spanish dry-cured ham. Food Chem. 2013, 138, 1282-1288. [CrossRef]

25. Stadnik, J.; Kęska, P. Meat and fermented meat products as a source of bioactive peptides. Acta Sci. Pol. Technol. Aliment. 2015, 14, 181-190. [CrossRef] [PubMed]

26. Udenigwe, C.C.; Aluko, R.E. Chemometric Analysis of the Amino Acid Requirements of Antioxidant Food Protein Hydrolysates. Int. J. Mol. Sci. 2011, 12, 3148-3161. [CrossRef] [PubMed] 
27. Faustino, A.M.; Veiga, M.; Sousa, P.; Costa, E.M.; Silva, S.; Pintado, M. Agro-Food Byproducts as a New Source of Natural Food Additives. Molecules 2019, 24, 1056. [CrossRef] [PubMed]

28. El-Saadony, M.T.; Saad, A.M.; Najjar, A.A.; Alzahrani, S.O.; Alkhatib, F.M.; Shafi, M.E.; Selem, E.; Desoky, E.-S.M.; Fouda, S.E.E.; El-Tahan, A.M. The use of biological selenium nanoparticles in controlling Triticum aestivum L. crown root and rot diseases induced by Fusarium species and improve yield under drought and heat stress. Saudi J. Biol. Sci. 2021, $28,4461-4471$.

29. El-Saadony, M.T.; Desoky, E.-S.M.; Saad, A.M.; Eid, R.S.; Selem, E.; Elrys, A.S. Biological silicon nanoparticles improve Phaseolus vulgaris L. yield and minimize its contaminant contents on a heavy metals-contaminated saline soil. J. Environ. Sci. 2021, 106, 1-14. [CrossRef]

30. Dueñas, M.; Martínez-Villaluenga, C.; Limón, R.I.; Peñas, E.; Frias, J. Effect of germination and elicitation on phenolic composition and bioactivity of kidney beans. Food Res. Int. 2015, 70, 55-63. [CrossRef]

31. Romero, J.; Sun, S.-M.M.; McLeester, R.C.; Bliss, F.A.; Hall, T.C. Heritable Variation in a Polypeptide Subunit of the Major Storage Protein of the Bean, Phaseolus vulgaris L. Plant. Physiol. 1975, 56, 776-779. [CrossRef]

32. Los, F.G.B.; Demiate, I.M.; Dornelles, R.C.P.; Lamsal, B. Enzymatic hydrolysis of Carioca bean (Phaseolus vulgaris L.) protein as an alternative to commercially rejected grains. LWT 2020, 125, 109191. [CrossRef]

33. Mamboya, E.A.F. Papain, a plant enzyme of biological importance: A review. Am. J. Biochem. Biotechnol. 2012, 8, 99-104.

34. Sarmadi, B.H.; Ismail, A. Antioxidative peptides from food proteins: A review. Peptides 2010, 31, 1949-1956. [CrossRef]

35. Noman, A.; Xu, Y.; Al-Bukhaiti, W.Q.; Abed, S.M.; Ali, A.; Ramadhan, A.H.; Xia, W. Influence of enzymatic hydrolysis conditions on the degree of hydrolysis and functional properties of protein hydrolysate obtained from Chinese sturgeon (Acipenser sinensis) by using papain enzyme. Process. Biochem. 2018, 67, 19-28. [CrossRef]

36. Bumrungsart, N.; Duangmal, K. Optimization of Enzymatic Hydrolysis Condition for Producing Black Gram Bean (Vigna mungo) Hydrolysate with High Antioxidant Activity. Food Appl. Biosci. J. 2019, 7, 105-117.

37. Meshginfar, N.; Mahoonak, A.S.; Ghorbani, M.; Aalami, M. Effects of Protein Hydrolysate from Sheep Visceral on Oxidative Stability of Soybean Oil and Chicken Sausage. J. Food Process. Preserv. 2016, 41, e12875. [CrossRef]

38. El-Saadony, M.T.; Elsadek, M.F.; Mohamed, A.S.; Taha, A.E.; Ahmed, B.M.; Saad, A.M. Effects of chemical and natural additives on cucumber juice's quality, shelf life, and safety. Foods 2020, 9, 639. [CrossRef]

39. Saad, A.M.; Mohamed, A.S.; El-Saadony, M.T.; Sitohy, M.Z. Palatable functional Cucumber juices supplemented with polyphenols-rich herbal extracts. LWT- Food Sci. Technol. 2021, 148, 111668. [CrossRef]

40. Johnson, E.A.; Brekke, C.J. Functional Properties of Acylated Pea Protein Isolates. J. Food Sci. 1983, 48, 722-725. [CrossRef]

41. Holye, N.T.; Merrltt, J.H. Quality of fish protein hydrolysates from herring (Clupea harengus). J. Food Sci. 1994, 59, 76-79. [CrossRef]

42. Laemmli, U.K. Cleavage of Structural Proteins during the Assembly of the Head of Bacteriophage T4. Nature 1970, 227, 680-685. [CrossRef]

43. Roy, M.; Sarker, A.; Azad, A.K.; Shaheb, R.; Hoque, M. Evaluation of antioxidant and antimicrobial properties of dark red kidney bean (Phaseolus vulgaris) protein hydrolysates. J. Food Meas. Charact. 2019, 14, 303-313. [CrossRef]

44. Chobert, J.-M.; Touati, A.; Bertrand-Harb, C.; Dalgalarrondo, M.; Nicolas, M.-G.; Haertle, T. In vitro proteolysis and functional properties of reductively alkylated $\beta$-casein derivatives. J. Dairy Res. 1991, 58, 285-298. [CrossRef]

45. AOAC. Official Methods of Analysis, 18th ed.; Pub AOAC International Maryland: Rockville, MD, USA, 2005.

46. Wani, I.A.; Sogi, D.; Gill, B.S. Physicochemical and functional properties of flours from three Black gram (Phaseolus mungo L.) cultivars. Int. J. Food Sci. Technol. 2012, 48, 771-777. [CrossRef]

47. Wani, I.A.; Sogi, D.S.; Gill, B.S. Physico-chemical and functional properties of native and hydrolysed protein isolates from Indian black gram (Phaseolus mungo L.) cultivars. LWT 2015, 60, 848-854. [CrossRef]

48. Škerget, M.; Kotnik, P.; Hadolin, M.; Hraš, A.R.; Simonič, M.; Knez, Ž. Phenols, proanthocyanidins, flavones and flavonols in some plant materials and their antioxidant activities. Food Chem. 2005, 89, 191-198. [CrossRef]

49. Ordonez, A.; Gomez, J.; Vattuone, M.; Lsla, M. Antioxidant activities of Sechium edule (Jacq.) Swartz extracts. Food Chem. 2006, 97, 452-458. [CrossRef]

50. Giusti, M.; Wrolstad, R.E. Characterization and Measurement of Anthocyanins by UV-Visible Spectroscopy. Curr. Protoc. Food Anal. Chem. 2001. [CrossRef]

51. Hatano, T.; Kagawa, H.; Yasuhara, T.; Okuda, T. Two new flavonoids and other constituents in licorice root. Their relative astringency and radical scavenging effects. Chem. Pharm. Bull. 1988, 36, 2090-2097. [CrossRef]

52. Dastmalchi, K.; Dorman, H.D.; Laakso, I.; Hiltunen, R. Chemical composition and antioxidative activity of Moldavian balm (Dra-cocephalum moldavica L.) extracts. LWT- Food Sci. Technol. 2007, 40, 1655-1663. [CrossRef]

53. El-Saadony, M.T.; Alkhatib, F.M.; Alzahrani, S.O.; Shafi, M.E.; Abdel-Hamid, S.E.; Taha, T.F.; Aboelenin, S.M.; Soliman, M.M.; Ahmed, N.H. Impact of mycogenic zinc nanoparticles on performance, behavior, immune response, and microbial load in Oreochromis niloticus. Saudi J. Biol. Sci. 2021, 28, 4592-4604. [CrossRef]

54. El-Saadony, M.T.; El-Wafai, N.A.; El-Fattah, H.I.A.; Mahgoub, S. Biosynthesis, Optimization and Characterization of Silver Nanoparticles Using a Soil Isolate of Bacillus pseudomycoides MT32 and their Antifungal Activity Against some Pathogenic Fungi. Adv. Anim. Vet. Sci. 2019, 7, 238-249. [CrossRef]

55. Alizadeh, H.; Rahnema, M.; Semnani, S.N.; Ajalli, M. Synergistic antifungal effects of quince leaf's extracts and silver nanoparticles on Aspergillus niger. J. Appl. Biol. Sci. 2014, 8, 10-13. 
56. Özyurt, G.; Kuley, E.; Balikçi, E.; Kaçar, Ç; Gökdogan, S.; Etyemez, M.; Ozogul, F. Effect of the Icing with Rosemary Extract on the Oxidative Stability and Biogenic Amine Formation in Sardine (Sardinella aurita) During Chilled Storage. Food Bioprocess. Technol. 2011, 5, 2777-2786. [CrossRef]

57. Badr, H.M. Antioxidative activity of carnosine in gamma irradiated ground beef and beef patties. Food Chem. 2007, 104, 665-679. [CrossRef]

58. Krzywicki, K. The determination of haem pigments in meat. Meat Sci. 1982, 7, 29-36. [CrossRef]

59. Niehaus Jr, W.; Samuelsson, B. Formation of malonaldehyde from phospholipid arachidonate during microsomal lipid peroxidation. Eur. J. Biochem. 1968, 6, 126-130. [CrossRef] [PubMed]

60. Idakwo, P.Y.; Negbenebor, C.A.; Badau, M.H.; Gbenyi, D.I. Total volatile base nitrogen (TVBN) and trimethylamine (TMA) content of "Bunyi youri" as influenced by the addition of glucose and clove during storage. Int. J. Biotechnol. Food Sci. 2016, 4, 81-85.

61. Piga, A.; Catzeddu, P.; Farris, S.; Roggio, T.; Sanguinetti, A.; Scano, E. Texture evolution of "Amaretti" cookies during storage. Eur. Food Res. Technol. 2005, 221, 387-391. [CrossRef]

62. Hunter, R. Scales for the Measurements of Color Difference. The Measurement of Appearance; John Willy \& Sons: New York, NY, USA, 1975; pp. 133-140.

63. Saad, A.M.; El-Saadony, M.T.; Mohamed, A.S.; Ahmed, A.I.; Sitohy, M.Z. Impact of cucumber pomace fortification on the nutri-tional, sensorial and technological quality of soft wheat flour-based noodles. Int. J. Food Sci. Technol. 2021, 56, 3255-3268. [CrossRef]

64. Abdelnour, S.; El-Saadony, M.; Saghir, S.; El-Hack, M.A.; Al-Shargi, O.; Al-Gabri, N.; Salama, A. Mitigating negative impacts of heat stress in growing rabbits via dietary prodigiosin supplementation. Livest. Sci. 2020, 240, 104220. [CrossRef]

65. Reda, F.M.; El-Saadony, M.T.; ElNesr, S.S.; Alagawany, M.; Tufarelli, V. Effect of Dietary Supplementation of Biological Curcumin Nanoparticles on Growth and Carcass Traits, Antioxidant Status, Immunity and Caecal Microbiota of Japanese Quails. Animals 2020, 10, 754. [CrossRef]

66. Reda, F.M.; El-Saadony, M.T.; El-Rayes, T.K.; Attia, A.I.; El-Sayed, S.A.; Ahmed, S.Y.; Madkour, M.; Alagawany, M. Use of biological nano zinc as a feed additive in quail nutrition: Biosynthesis, antimicrobial activity and its effect on growth, feed utilisation, blood metabolites and intestinal microbiota. Ital. J. Anim. Sci. 2021, 20, 324-335. [CrossRef]

67. Sheiha, A.M.; Abdelnour, S.A.; El-Hack, A.; Mohamed, E.; Khafaga, A.F.; Metwally, K.A.; Ajarem, J.S.; Maodaa, S.N.; Allam, A.A.; El-Saadony, M.T. Effects of dietary biological or chemical-synthesized nano-selenium supplementation on growing rabbits ex-posed to thermal stress. Animals 2020, 10, 430. [CrossRef]

68. Evangelho, J.A.d.; Berrios, J.d.J.; Pinto, V.Z.; Antunes, M.D.; Vanier, N.L.; Zavareze, E.d.R. Antioxidant activity of black bean (Phaseolus vulgaris L.) protein hydrolysates. Food Sci. Technol. 2016, 36, 23-27. [CrossRef]

69. del Mar Yust, M.; Pedroche, J.; del Carmen Millán-Linares, M.; Alcaide-Hidalgo, J.M.; Millán, F. Improvement of functional prop-erties of chickpea proteins by hydrolysis with immobilised Alcalase. Food Chem. 2010, 122, 1212-1217. [CrossRef]

70. Evangelho, J.A.D.; Vanier, N.; Pinto, V.Z.; De Berrios, J.J.; Dias, A.R.G.; Zavareze, E.D.R. Black bean (Phaseolus vulgaris L.) protein hydrolysates: Physicochemical and functional properties. Food Chem. 2017, 214, 460-467. [CrossRef]

71. de Toledo, N.M.V.; Rocha, L.C.; da Silva, A.G.; Brazaca, S.G.C. Interaction and digestibility of phaseolin/polyphenol in the common bean. Food Chem. 2013, 138, 776-780. [CrossRef]

72. Abdel-Hamid, M.; Otte, J.; De Gobba, C.; Osman, A.; Hamad, E. Angiotensin I-converting enzyme inhibitory activity and antioxi-dant capacity of bioactive peptides derived from enzymatic hydrolysis of buffalo milk proteins. Int. Dairy J. 2017, 66, 91-98. [CrossRef]

73. Moure, A.; Sineiro, J.; Domínguez, H.; Parajó, J.C. Functionality of oilseed protein products: A review. Food Res. Int. 2006, 39, 945-963. [CrossRef]

74. Osman, A.; El-Didamony, G.; Sitohy, M.; Khalifa, M.; Enan, G. Soybean glycinin basic subunit inhibits methicillin re-sistantvancomycin intermediate Staphylococcus aureus (MRSA-VISA) in vitro. Int. J. Appl. Res. Nat. Prod. 2016, 9, 17-26.

75. Wahdan, K.; Saad, A. Antibacterial and Antioxidant Activities of an Enzymatic Hydrolysate Kidney Bean (Phaseolus vulgaris L.) Protein Isolates. J. Agric. Chem. Biotechnol. 2018, 9, 85-89. [CrossRef]

76. Eckert, E.; Han, J.; Swallow, K.; Tian, Z.; Jarpa-Parra, M.; Chen, L. Effects of enzymatic hydrolysis and ultrafiltration on physico-chemical and functional properties of faba bean protein. Cereal Chem. 2019, 96, 725-741. [CrossRef]

77. Sarker, A.; Chakraborty, S.; Roy, M. Dark red kidney bean (Phaseolus vulgaris L.) protein hydrolysates inhibit the growth of oxidizing substances in plain yogurt. J. Agric. Food Res. 2020, 2, 100062. [CrossRef]

78. Jakobek, L. Interactions of polyphenols with carbohydrates, lipids and proteins. Food Chem. 2015, 175, 556-567. [CrossRef]

79. Torre, P.; Aliakbarian, B.; Rivas, B.; Domínguez, J.M.; Converti, A. Release of ferulic acid from corn cobs by alkaline hydrolysis. Biochem. Eng. J. 2008, 40, 500-506. [CrossRef]

80. Vijitpunyaruk, T.; Theerakulkait, C. Preparation of alcalase hydrolysed rice bran protein concentrate and its inhibitory effect on soybean lipoxygenase activity. Int. J. Food Sci. Technol. 2013, 49, 501-507. [CrossRef]

81. Esfandi, R.; Walters, M.E.; Tsopmo, A. Antioxidant properties and potential mechanisms of hydrolyzed proteins and peptides from cereals. Heliyon 2019, 5, e01538. [CrossRef] [PubMed]

82. Nwachukwu, I.D.; Aluko, R.E. Structural and functional properties of food protein-derived antioxidant peptides. J. Food Biochem. 2019, 43, e12761. [CrossRef] [PubMed] 
83. Breijyeh, Z.; Jubeh, B.; Karaman, R. Resistance of Gram-Negative Bacteria to Current Antibacterial Agents and Approaches to Resolve It. Molecules 2020, 25, 1340. [CrossRef]

84. Benkerroum, N. Antimicrobial peptides generated from milk proteins: A survey and prospects for application in the food industry. A review. Int. J. Dairy Technol. 2010, 63, 320-338. [CrossRef]

85. Lei, J.; Sun, L.; Huang, S.; Zhu, C.; Li, P.; He, J.; Mackey, V.; Coy, D.H.; He, Q. The antimicrobial peptides and their potential clinical applications. Am. J. Transl. Res. 2019, 11, 3919-3931.

86. Karabagias, I.; Badeka, A.; Kontominas, M. Shelf life extension of lamb meat using thyme or oregano essential oils and modified atmosphere packaging. Meat Sci. 2011, 88, 109-116. [CrossRef] [PubMed]

87. Chaijan, M. Lipid and myoglobin oxidations in muscle foods. Songklanakarin J. Sci. Technol. 2008, 30, 47-53.

88. Citta, A.; Folda, A.; Scalcon, V.; Scutari, G.; Bindoli, A.; Bellamio, M.; Feller, E.; Rigobello, M.P. Oxidative changes in lipids, proteins, and antioxidants in yogurt during the shelf life. Food Sci. Nutr. 2017, 5, 1079-1087. [CrossRef]

89. Piñuel, M.L.; Vilcacundo, E.; Boeri, P.A.; Barrio, D.A.; Morales, D.; Pinto, A.; Moran, R.; Samaniego, I.; Carrillo, W. Extraction of protein concentrate from red bean (Phaseolus vulgaris L.): Antioxidant activity and inhibition of lipid peroxidation. J. Appl. Pharm. Sci. 2019, 9, 1-14.

90. Aslam, S.; Shukat, R.; Khan, M.I.; Shahid, M. Effect of Dietary Supplementation of Bioactive Peptides on Antioxidant Potential of Broiler Breast Meat and Physicochemical Characteristics of Nuggets. Food Sci. Anim. Resour. 2020, 40, 55-73. [CrossRef]

91. Ab Aziz, M.F.; Hayat, M.N.; Kaka, U.; Kamarulzaman, N.H.; Sazili, A.Q. Physico-Chemical Characteristics and Microbiological Quality of Broiler Chicken Pectoralis Major Muscle Subjected to Different Storage Temperature and Duration. Foods 2020, 9, 741. [CrossRef]

92. Manigiri, G.; Prajapati, B.; Solanki, B.; Shishir, N.; Shendurse, A. Shelf Life Evaluation of Chicken Meat Nuggets Incorporated with Gooseberry (Pulp and Seed Coat) Powder as Natural Preservatives at Refrigerated Storage $\left(4 \pm 1^{\circ} \mathrm{C}\right)$. Int. J. Livest. Res. 2019, 9, 53-63. [CrossRef]

93. Egyptian Standard, S.E. Fresh Meat; Egyptian Organization for Standardization and Quality Control: Cairo, Egypt, 2004; (No.4334/2004). 